\author{
اثر اسيد آسكوربيك و اسانس آويشن زوفايى بر عمر پس از برداشت \\ و حفظ كيفيت ميوه توتفرنحى \\ جواد عرفانى مقدم 1* و عشر ا محمدى

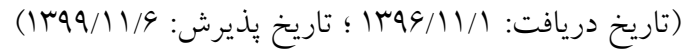

جكيده

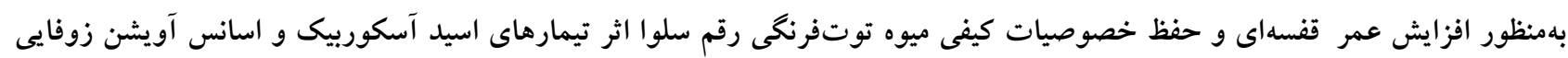
(Thymbra spicata)

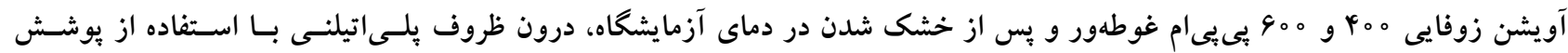

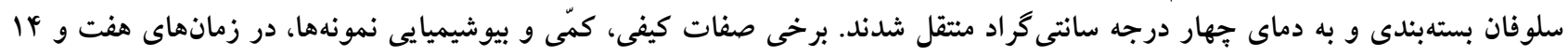

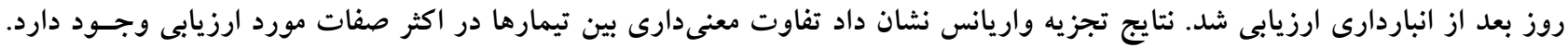

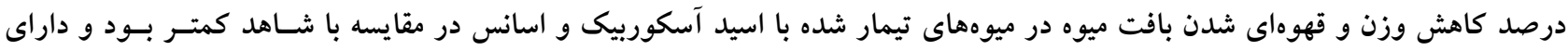

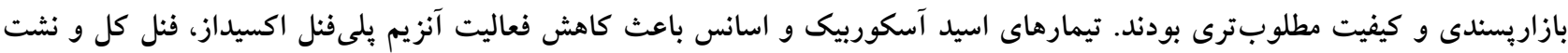

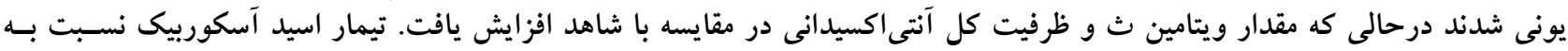

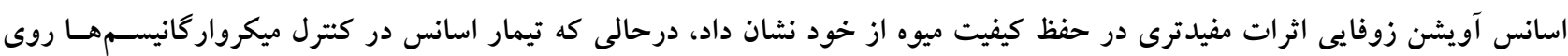

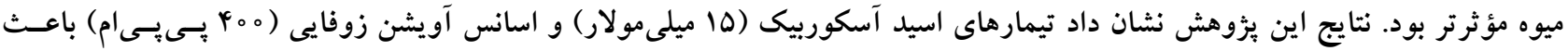

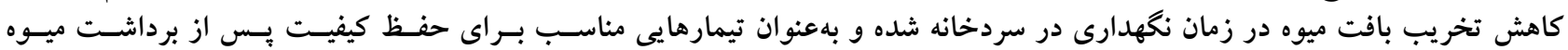
توت فرنغى هستند.

$$
\text { وازههاى كليدى: توتفرنكى، ظرفيت آنتىاكسيدانت، ويتامين ث، بلىفنل اكسيداز }
$$




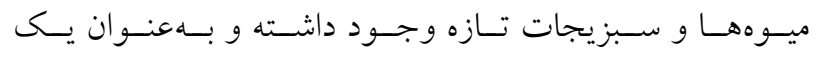

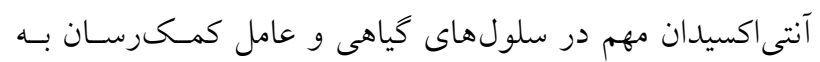

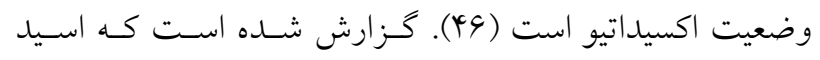

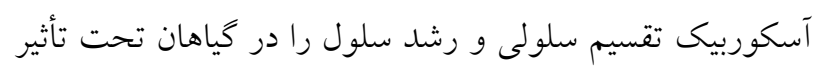

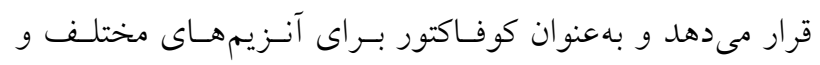

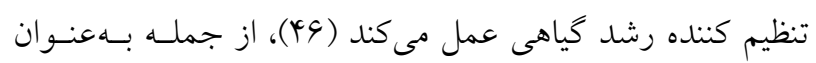

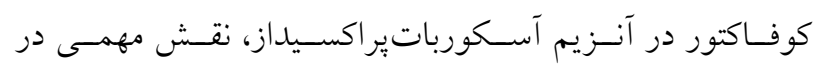

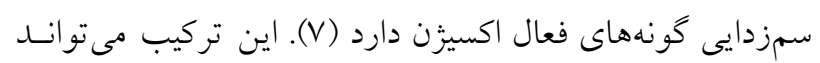

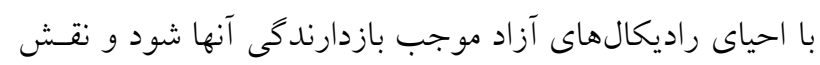

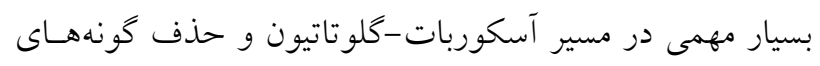

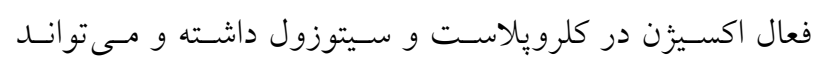

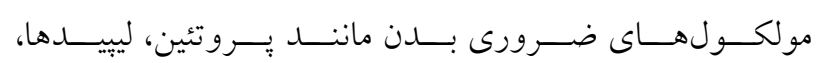

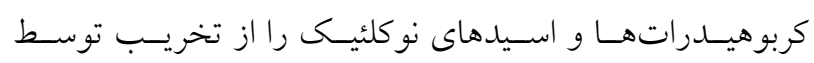

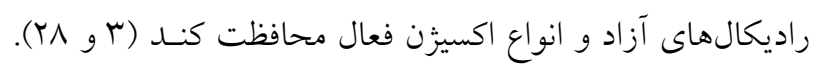

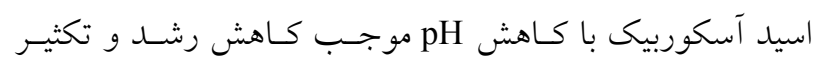

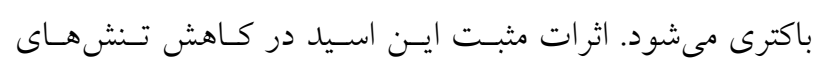

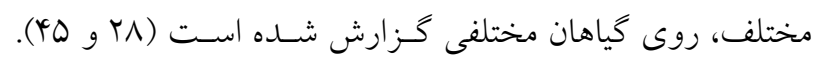

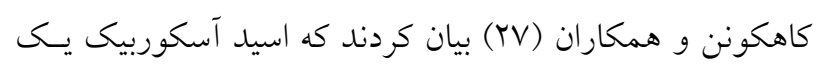

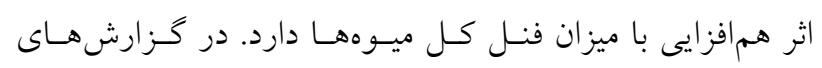

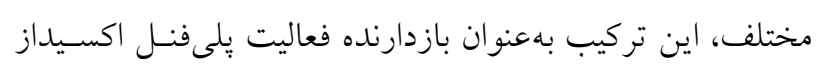

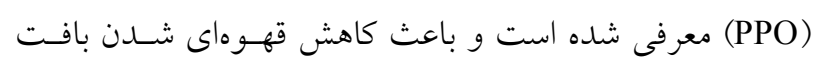

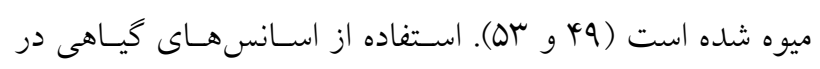

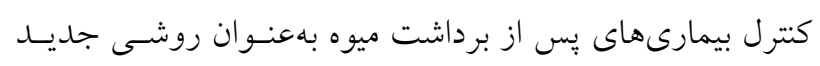

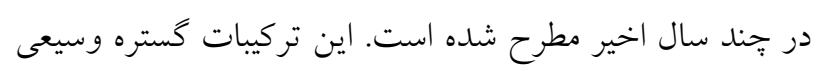

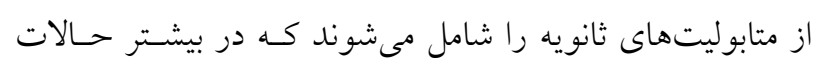

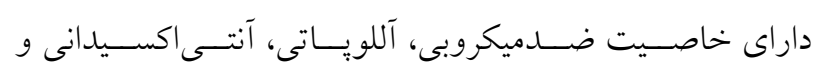

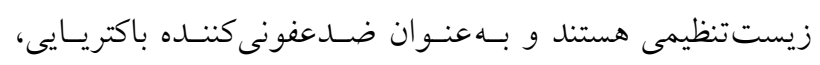

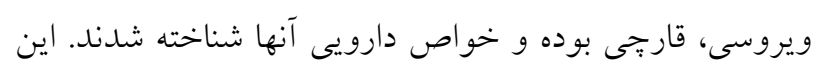

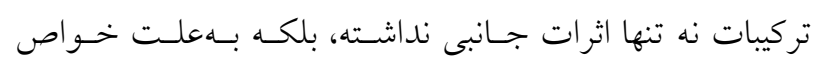

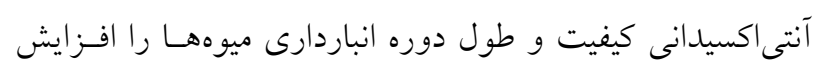

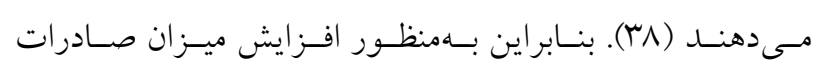

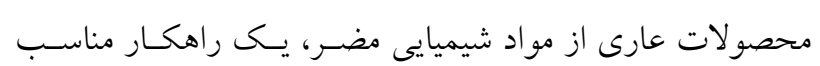

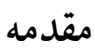

توتفرنكى (Fragaria ananassa) ميوهاى سرشـار از ويتـامين و

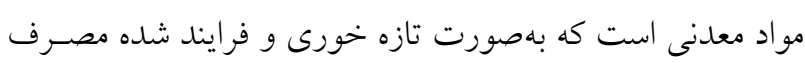

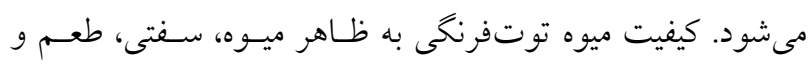

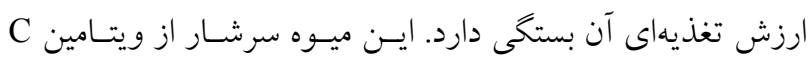

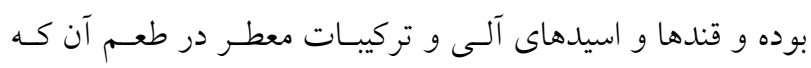

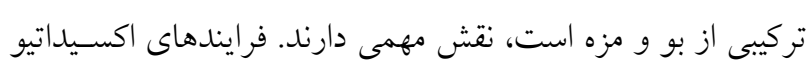

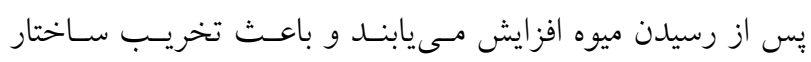

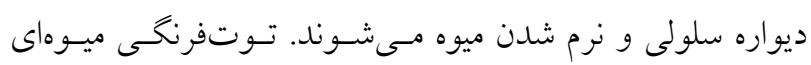

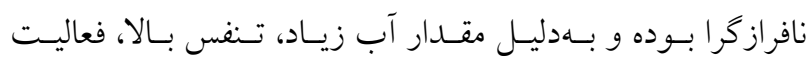

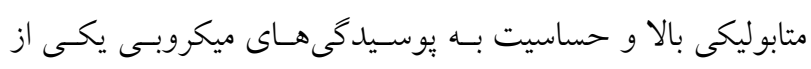

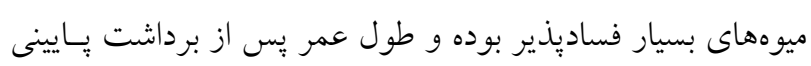

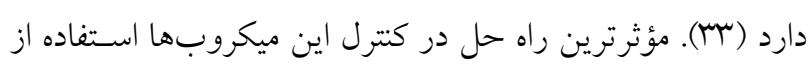

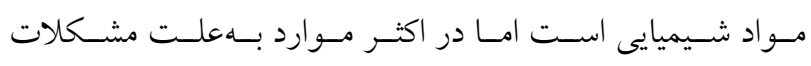
زيستمحيطى بازماندهاى سـموم، سـميت بــراى انسـان، ايجـاد

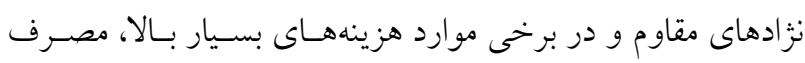

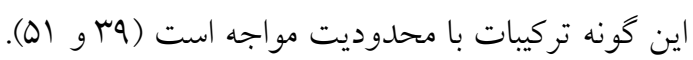

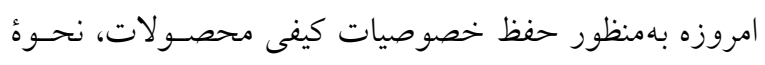
نخههارى محصولات كياهى بس از برداشت از اهميت و جايگاه

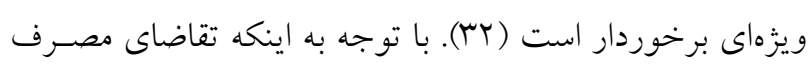

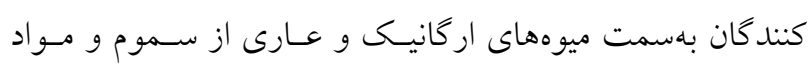

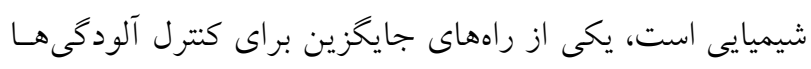

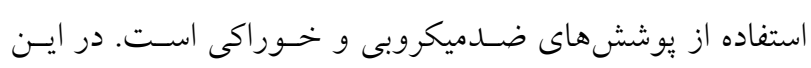

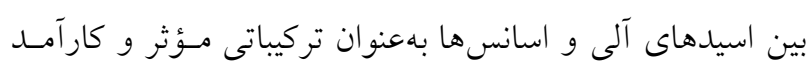
داراى خاصيت ضدميكروبى خوبى هستند و بهتازگى استـفاده از از

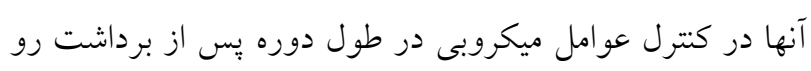

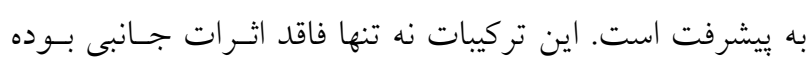

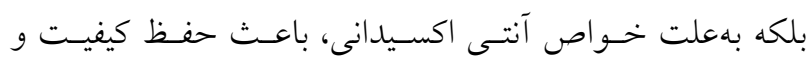

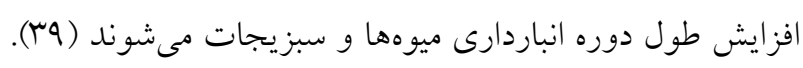

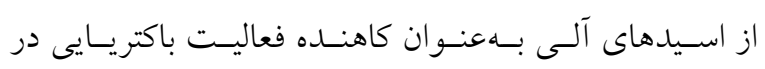

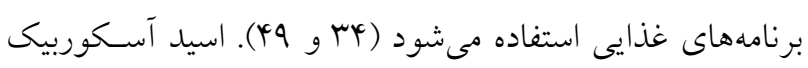
يك اسيد آلى ضعيف است كه بهطور طبيعى در بافت بسيارى از 


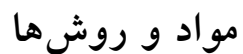

در اين يزؤهش ميوه توتفرنكى رقم سلوا در مرحلـه رسـيده و

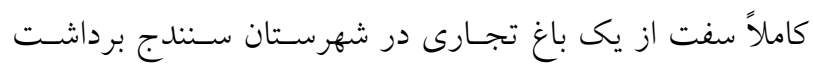

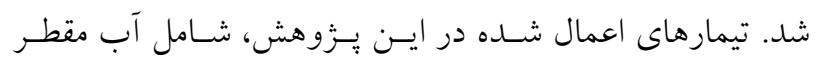

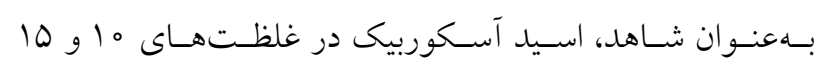

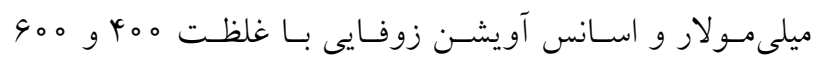

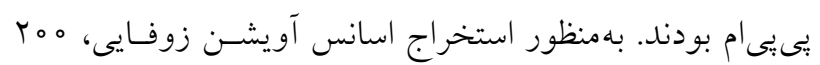

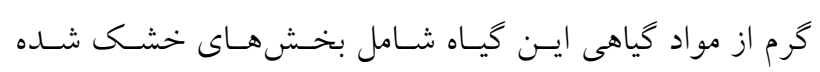
رويشى و زايشى (برك، ساقه و گل) بهطور كامل آسياب شـد و

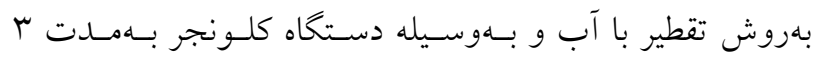

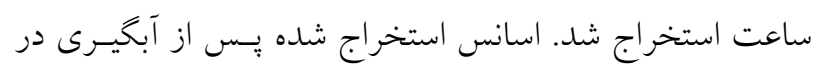

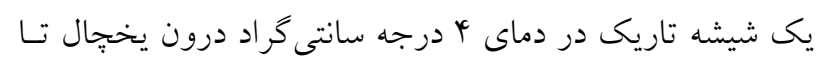

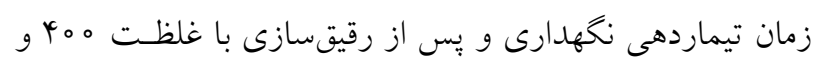

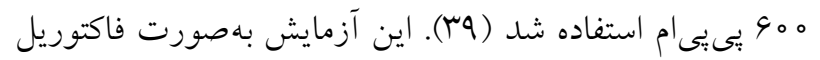

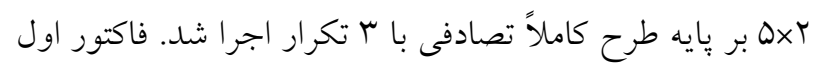
شامل تيمارهاى نامبرده و فاكتور دوم زمانهاى بررسىى (V روز و أ روز) درنظر كرفته شد. بس از تهيه غلظتهاى مورد نظر،

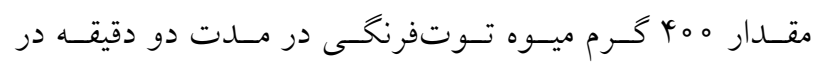

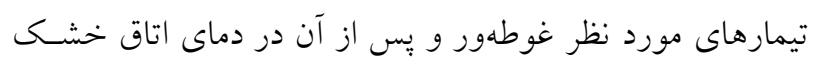

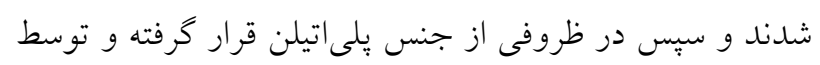

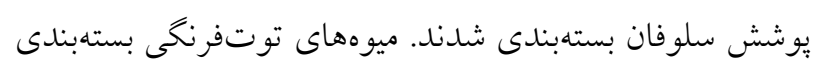

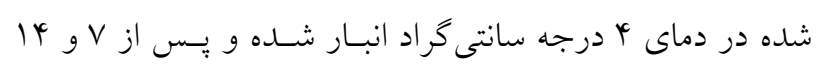
روز مورد ارزيابى قرار كرفتند. برخسى صـفات فيزيولـوزيكى و بيوشيميايى شامل درصد كاهش وزن، درصد مواد جامد محلول، درصد اسيد، pH عصـاره، درصــ نشـت يسونى، تعـداد كلـونى باكترى رشد يافته، كيفيت ظاهرى ميوه (بازاريسندى)، شـاخص طعه، فنل كل، ظرفيت كل آنتى اكسـيدانى، آنتوسـيانين، ويتـامين

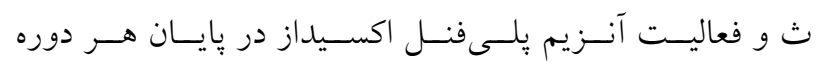
اندازه كيرى شدند. براى محاسبه كاهش وزن، نمونهها قبل از انباردارى با ترازوى

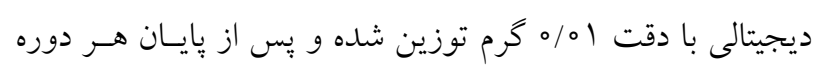

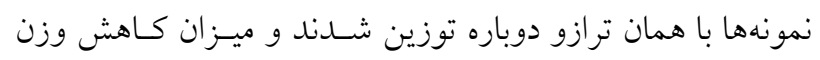

براى نخهارى محصولات در سطح تجارى محسوب مىشـوند

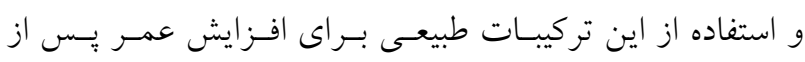
برداشت محصولات مختلف رو به افزايش اسـت. در يزوهشسى، براى افزايش ماندگاى ميوه گيلاس در سردخانه از زل آلوئسهورا

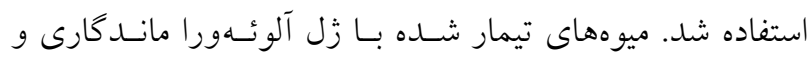
كيفيت بالاترى در مقايسه با ميوهاى شاهد داشتند. نتايج نشـان

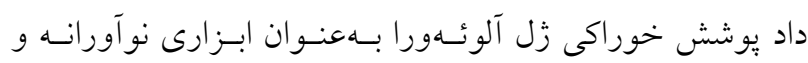
جالب براى كاربردهاى تجـارى و جـايخزينى بـراى اسـتفاده از تيمارهاى شيميايى در يس از برداشت است ( اسب). نتايج حاصل از اسـتفاده از اسـانس گياهـان رازيانسه، آويشـن و اسطوخودوس بهترتيب بر حفظ كيفيت بِ از برداشت سيب، انسار

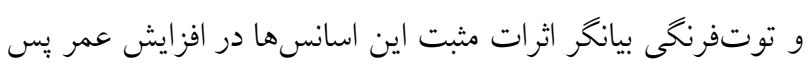

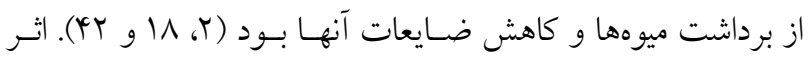

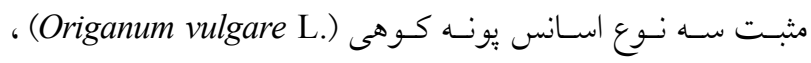
آويشـن (Thymus vulgaris L.) و ليمـو (Citrus limon L.) بـر

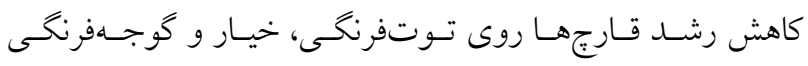
كزارش شد ( اله). در يزوهشى اثرات اسانس آويشن كوهى و باغى بر عمر يّ از برداشت توتفرنكى بررسى شـــ و نتـايج نشـان داد

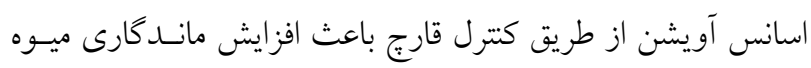

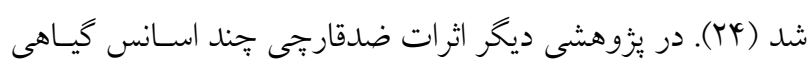
بر كترل بيمـارىهـاى قـارجى ميـوه تـوتفرنخـى در طـول دوره

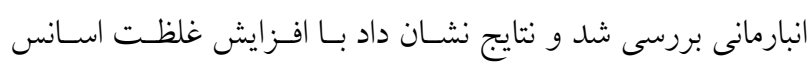

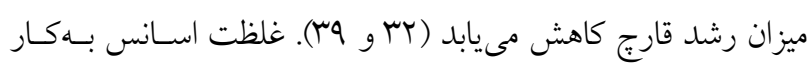
رفته در گياهان مختلف متفاوت بوده بـهــورى كـه در مـورد انـار

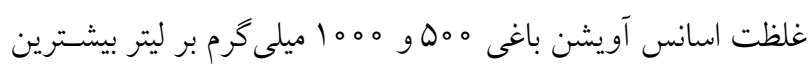
تأثير را بر كنترل ضايعات ميوه داشـته (YYC)، درحسالى كـه در مـورد توتفرنخى غلظت همب ميكروليتر بر ليتـر آويشـن بـاغى بيشـترين تأثير را نشان داده است (YY).

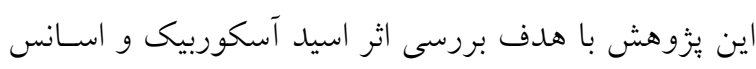

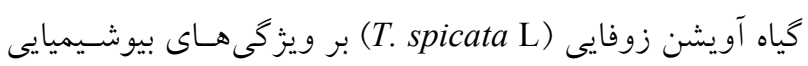

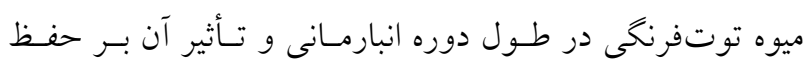
كيفيت و ماندگارى ميوه در زمان عرضه به بازار انجام شد. 
كاليكاسيد صورت گرفـت (Y) (Y). ميـزان جـذب نمونسه در طـول

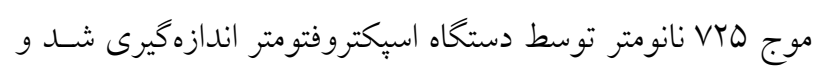

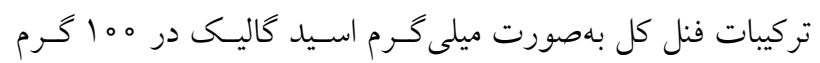
وزن تازه بهدست آمد.

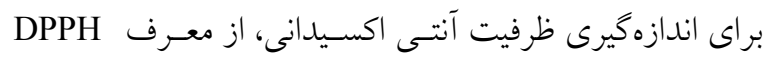
(2,2-diphenyl-1-picryl-hydrazyl-hydrate)

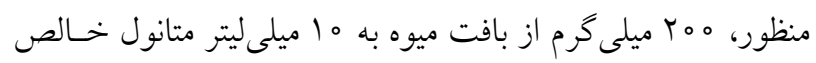

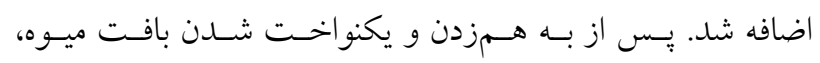

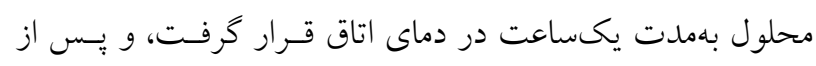

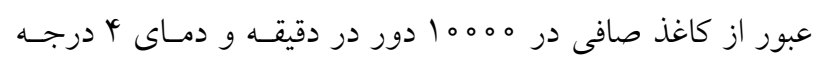

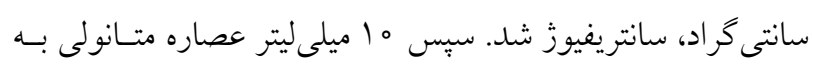

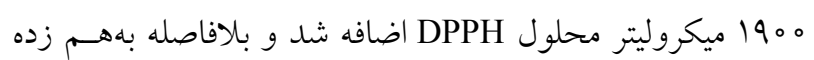

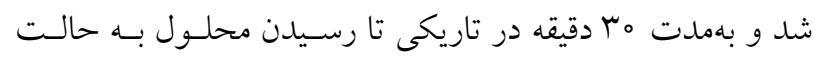

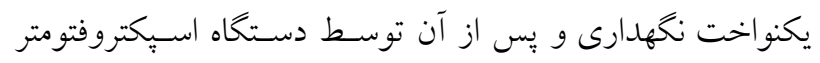

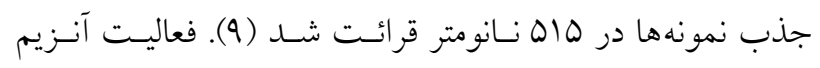

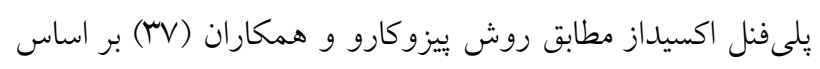

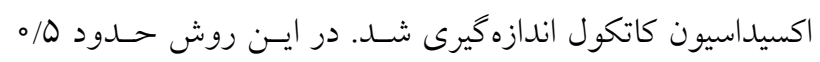

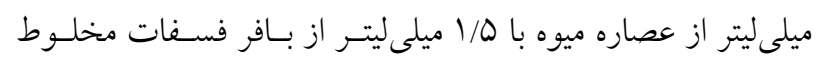

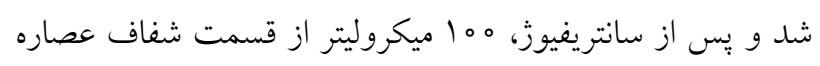

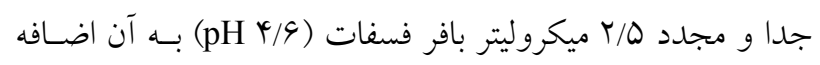

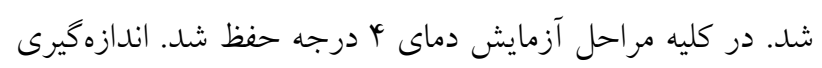

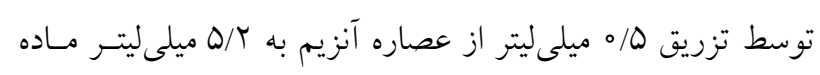

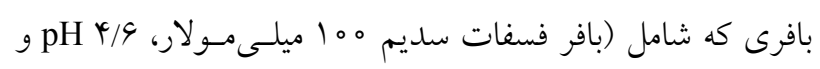

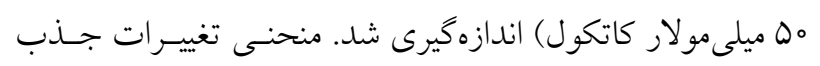

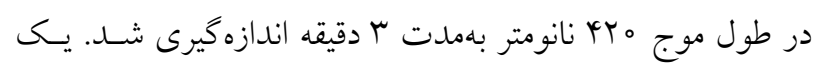

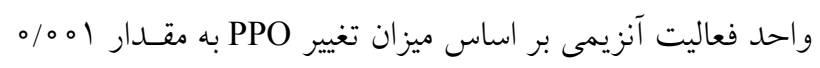

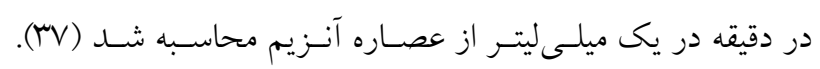

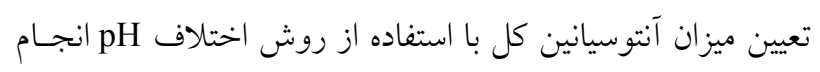

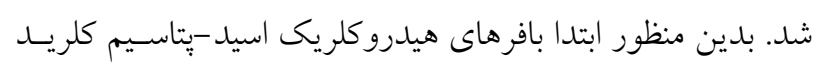

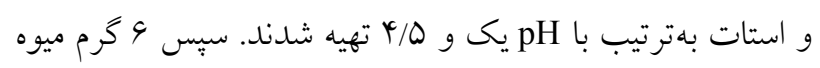

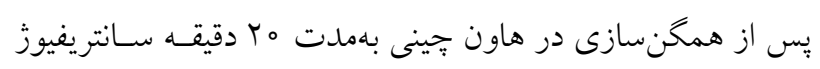

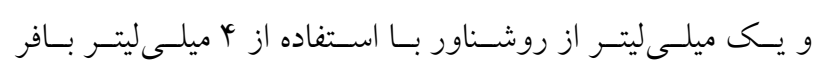

نمونهها بحسـب درصـــ محاسـبه شـــ (IV). مقــدار مـواد جامـــ

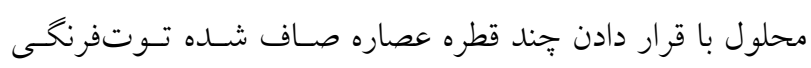

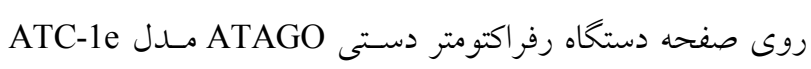

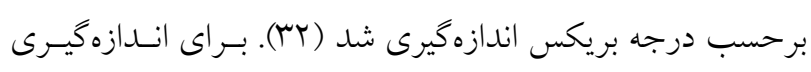

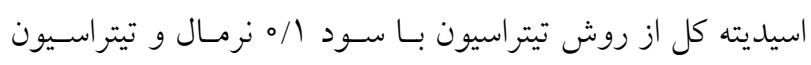

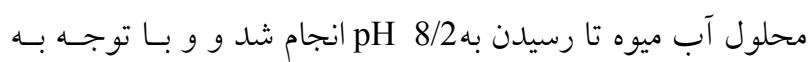
ميزان سود مصرفى در فرايند تيتراسيون ، ميزان درصد اسيديته كل مل مئل

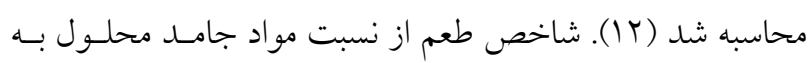

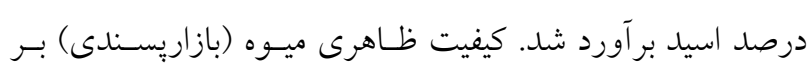
اساس نمرهدهى توسط ه نفر از ا تا ها برآورد شد كه نمره بـالاتر بيانكر بازاريسندى بهتر بود (19).

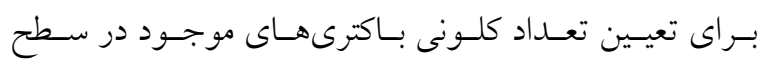

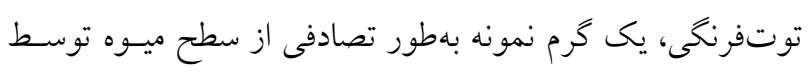

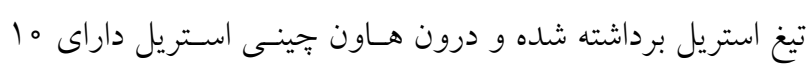

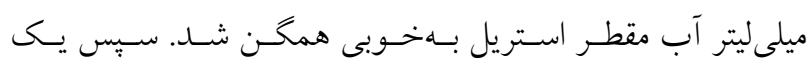

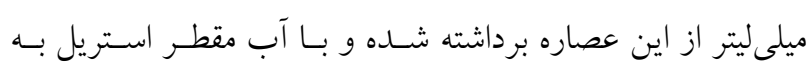
حجم ه 10 سى سى رسانده شد. يك قطره از سوسيانسـيون تهيـهـ

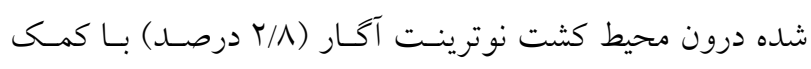

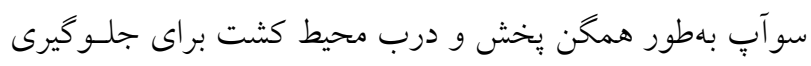

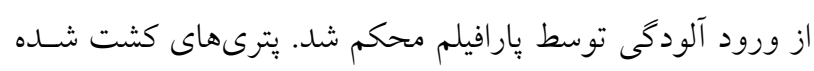

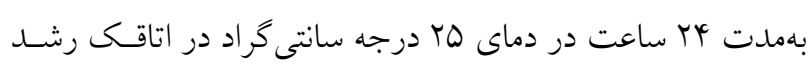

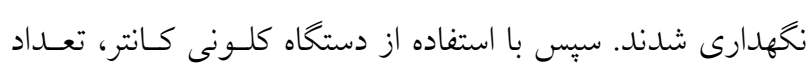

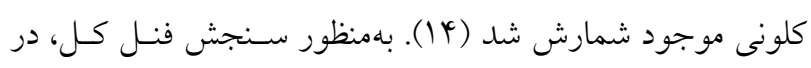

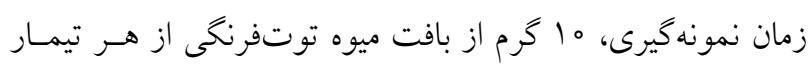

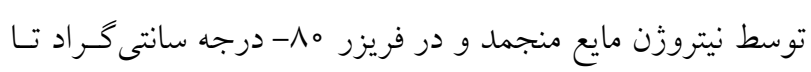

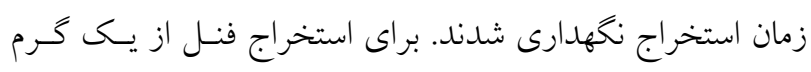

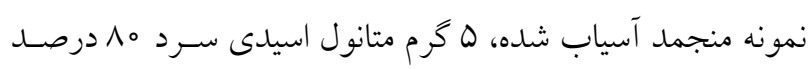

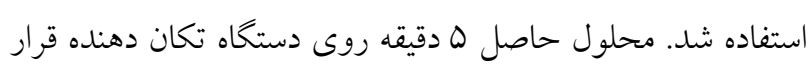

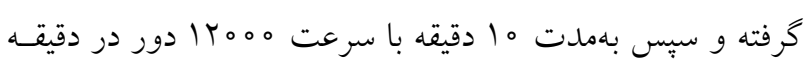

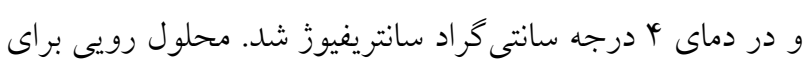

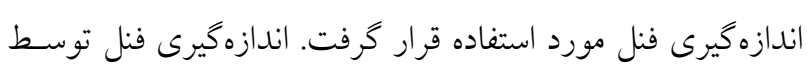

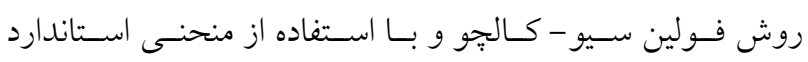


بايه طرح كاملاً تصادفى و مقايسه ميانكين ها با آزمـون دانكـن در سطح ينج درصد انجام شد.

\section{نتايج}

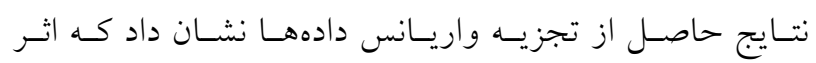

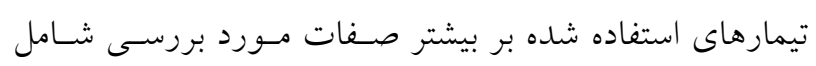

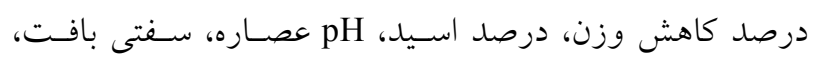

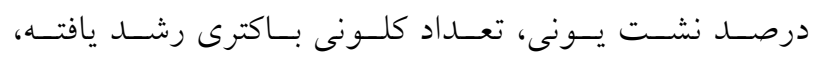

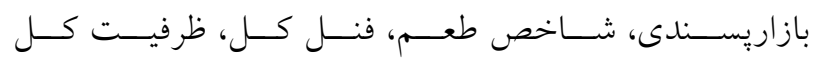

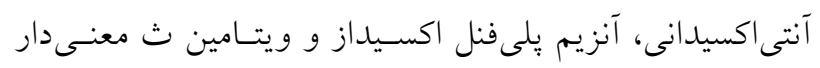

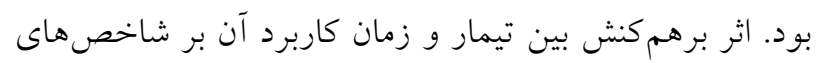

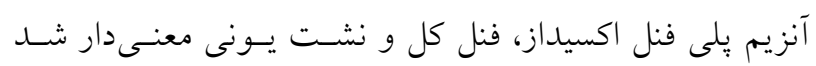

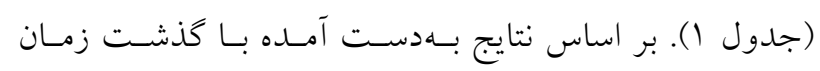

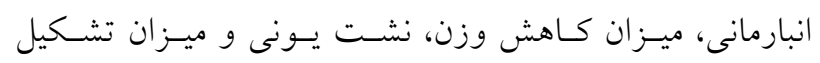
كلونى باكترى افزايش يافت، اما تيمارهاى اعمال شــده باعـث كاهش در اين فاكتورها شد. نتايج حاصل از تجزيه واريانس نشان داد كه اثر زمـان و اثـر

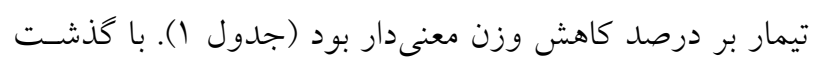

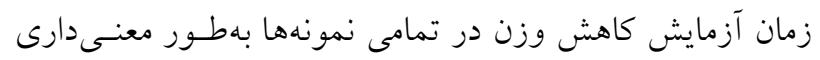

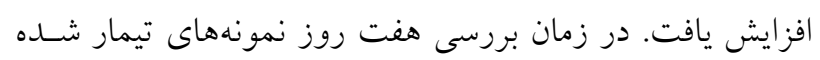

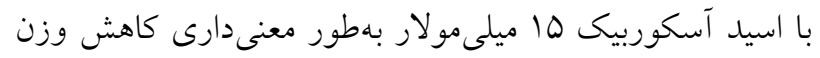

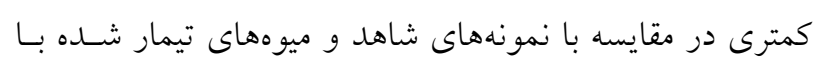

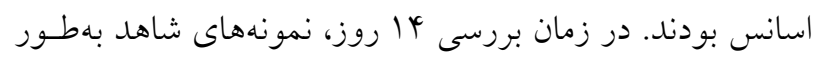
معنىدارى كاهش وزن بيشترى در مقايسه با ساير تيمارها نشـان

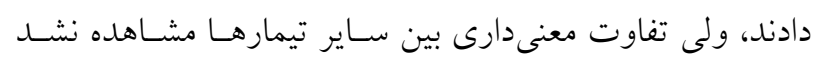
(جدول Y). همجنين بر اساس نتايج حاصل اثرات زمان و تيمار

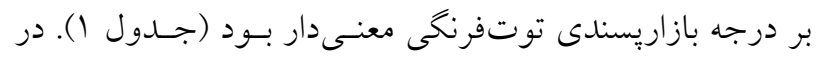

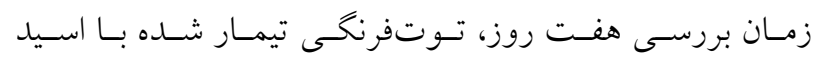

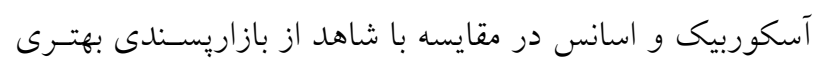

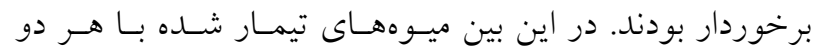
غلظت اسيد آسكوربيك و در درجه بعدى ميوههاى تيمـار شـاره

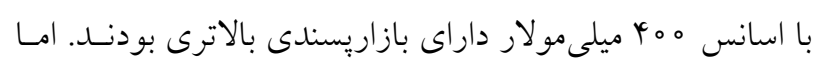

هيدروكلريك اسيد-يتاسيم كلريد رقيق و بههمـين ترتيـب مرتبـه

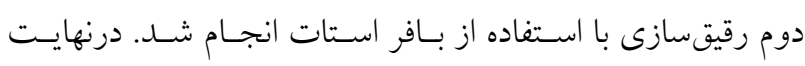

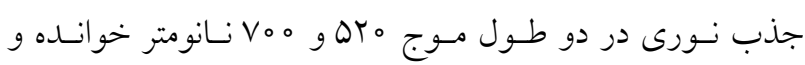

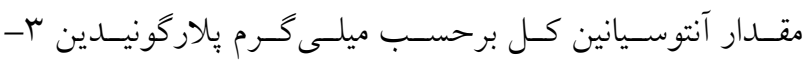

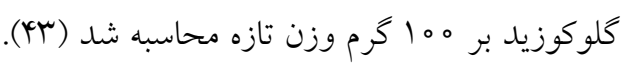

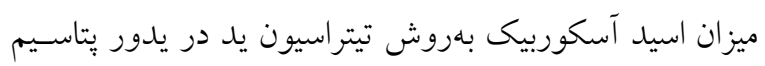

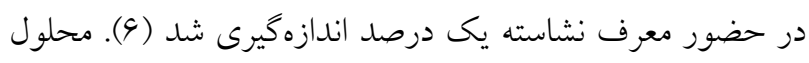
يد در يدور يتاسيم را براى تيتراسيون داخل بورت ريخته و حجم فمرنم اوليه محلول در بورت، يادداشت شد. مقدار ه اسىسى عصى عصـاره

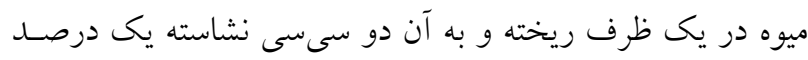

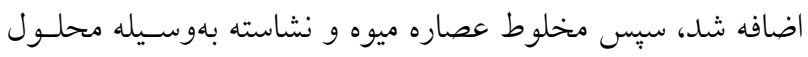

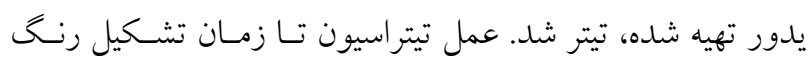

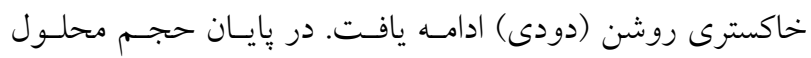

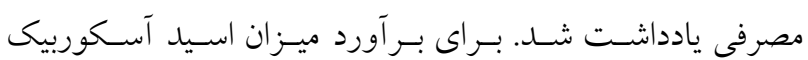

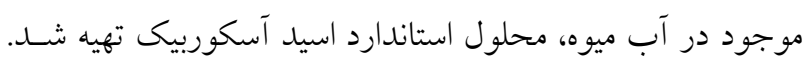

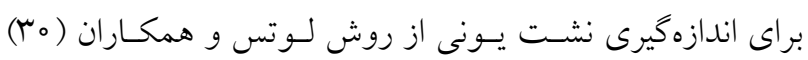

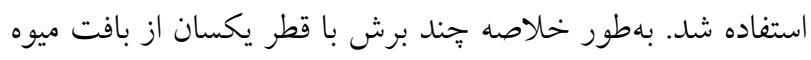

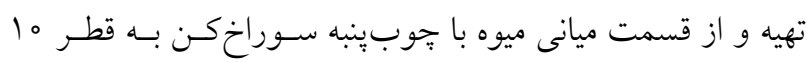

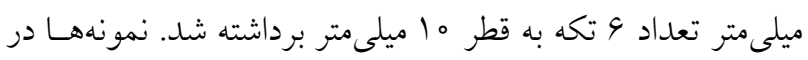

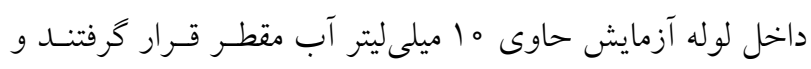

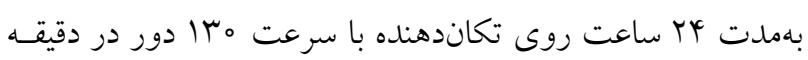

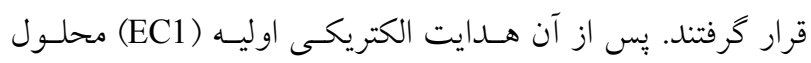

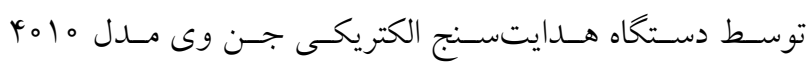

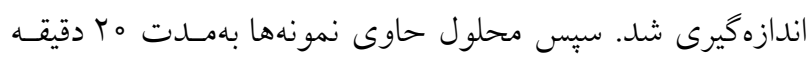

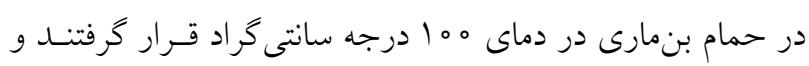

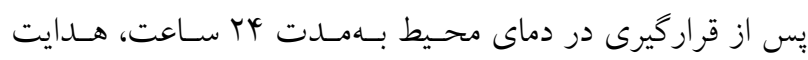

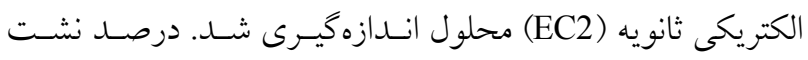

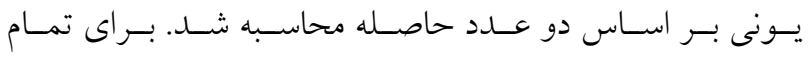

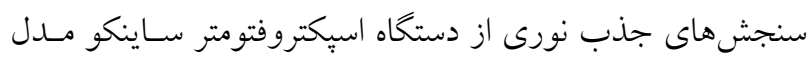

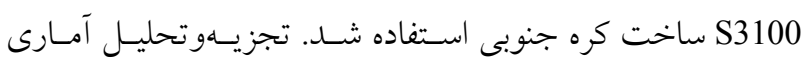

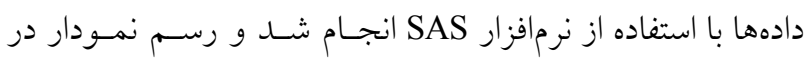
محيط Excel صورت كرفت. تجزيه طرح بـا روش فاكتوريـل بـر 
جدول ا. نتايج تجزيه واريانس برخى از صفات كمّى، كيفى و بيوشيميايى مورد بررسى در ميوه توت فرنخى

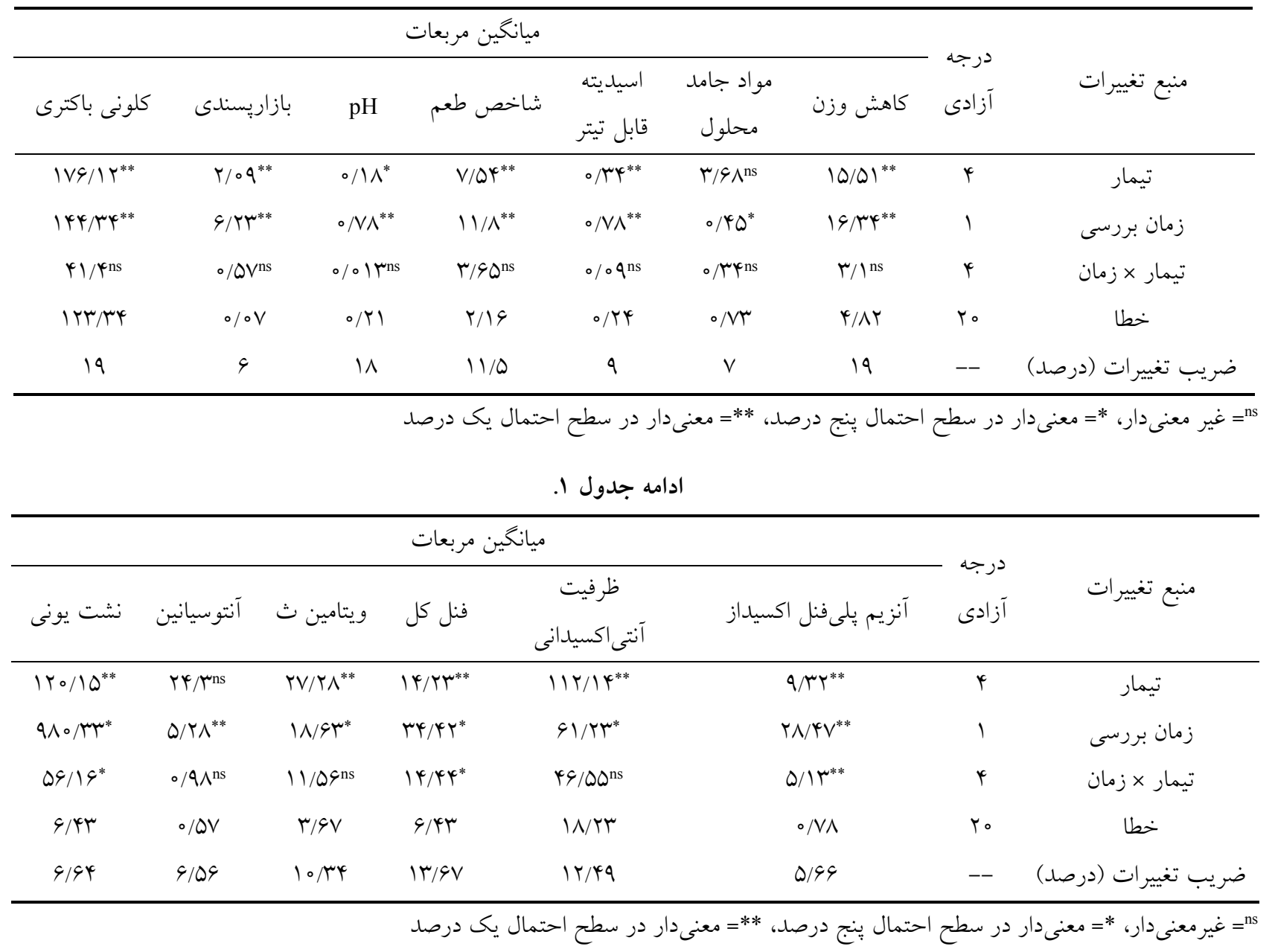

جدول r. مقايسه ميانگين اثرات تيمار اسيد آسكوربيك و اسانس آويشن زوفايى بر صفات كمّى و كيفى ميوه توت فرنگى بعد از انبارمانى

\begin{tabular}{|c|c|c|c|c|c|c|c|c|}
\hline ويتامين ث & آنى اكسيدانى & كلونى باكترى & بازاريسندى & $\mathrm{pH}$ & شاخص طعم & قابل تيتر & كاهش & تيمار \\
\hline$(\mathrm{mg} / \mathrm{g} \mathrm{fw})$ & $(\%)$ & (CFU) & (كد) & & (نسبت) & (\%) & $(\%)$ & \\
\hline $0 / 4 \mu^{c b}$ & $\| /\left.\right|^{\mathrm{c}}$ & $r \Lambda_{\circ} \mathrm{a}^{\mathrm{a}}$ & $\circ / \Lambda^{f}$ & $r / l V^{a}$ & $9 / \mathrm{N}^{\mathrm{a}}$ & $0 / 9 \mathrm{~V}^{\mathrm{b}}$ & $r|/ 4|^{\mathrm{a}}$ & شاهد \\
\hline$\circ / V Q^{a}$ & $\left\langle\psi /\left.\circ\right|^{a}\right.$ & $\mathrm{IV}^{\mathrm{b}}$ & $r / 9$ cab & $r / 10^{c}$ & $r / \kappa \mu^{b}$ & $1 / / 4 a$ & $N / q)$ bc & (ه اسيد آسكوربيكى \\
\hline$\circ /\left.\Lambda\right|^{a}$ & ${ }^{i} V / q^{a}$ & $1 r^{\mathrm{rc}}$ & $\varphi / 1 \varphi^{a}$ & $r / 01^{c}$ & $r / 19^{b}$ & $1 / \% \psi^{a}$ & $9 / K 4 \mathrm{c}$ & 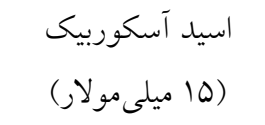 \\
\hline.$/ 49 b$ & $r 4 / 90^{\circ} \mathrm{b}$ & $19 \mathrm{~b}$ & $r / \Gamma^{b}$ & $r / q r^{a}$ & $0 / 4 q^{a}$ & $0 / 9 \mu^{\mathrm{b}}$ & $10 / 90 \mathrm{~b}$ & 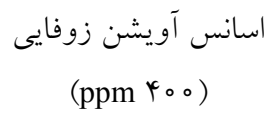 \\
\hline$\circ / V^{c}$ & $19 / 1 \wedge^{b}$ & $9^{d}$ & $r / q^{\mathrm{d}}$ & $r / 99^{a}$ & $\Delta / Y^{y^{a}}$ & $0 / 90^{\mathrm{b}}$ & $11 / 1 \wedge^{b}$ & 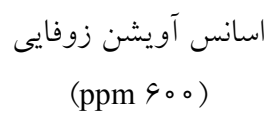 \\
\hline
\end{tabular}

در هر ستون ميانكينهايى كه داراى حروف مشابه در هر صفت هستند تفاوت معنىدارى نسبت به يكديكر در سطح پينج درصد آزمون دانكن ندارند. 
(lo/V)

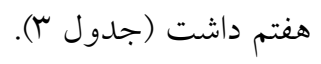

نتايج نشان داد اثر تيمارهاى استفاده شده و زمان بر اسـيديته

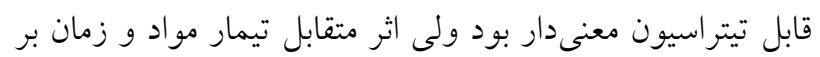
اسيديته قابل تيتراسيون معنى دار نبود (جدول (). در تيمار شاهد

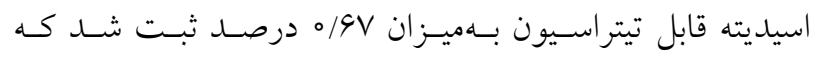
كمترين مقدار بود، اما تفاوت معنسى دارى بـين نمونـه شـاهد بـاــا

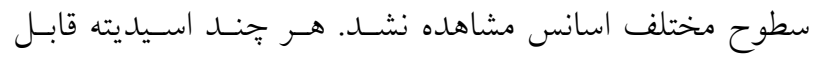

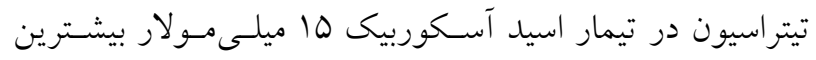

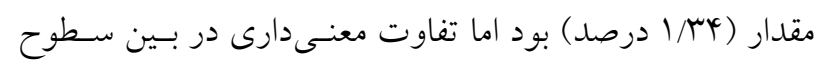

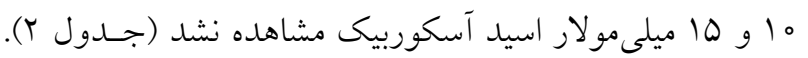

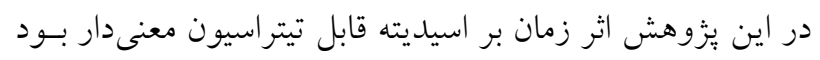

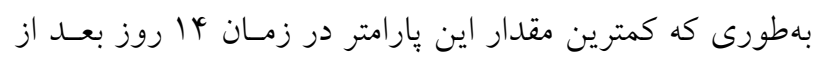

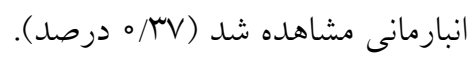

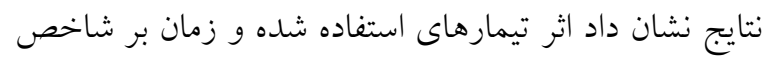

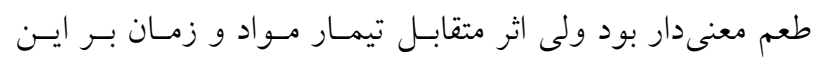

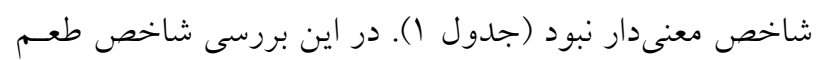

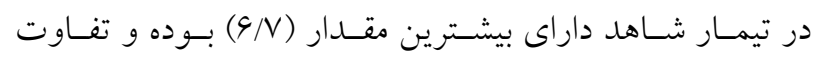
معنى دارى با سطوح مختلف اسـانس آويشـن زوفـايى نداشـت.

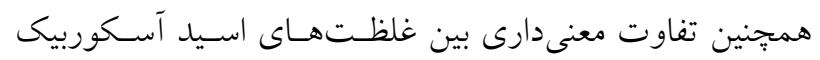
مشاهده نشد (جدول Y). اثر زمان بر شاخص طعم معنى دار بود.

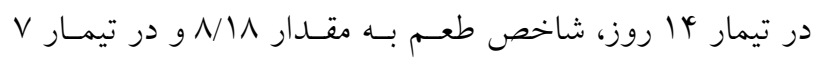

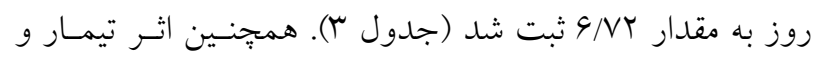

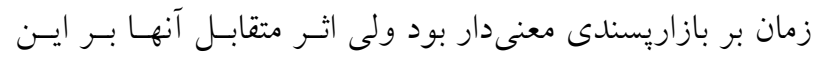

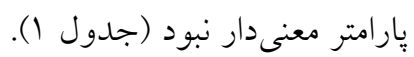

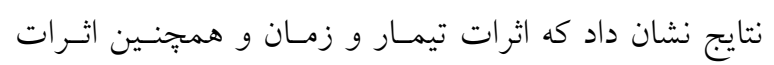

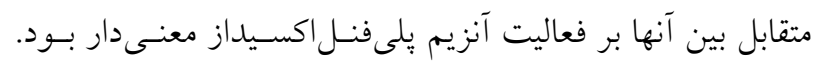

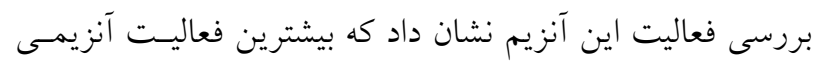

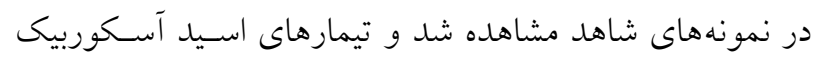

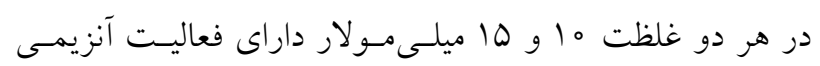
كمترى در مقايسه با شاهل بودند. در اين بين نمونسهــاى تيمـار

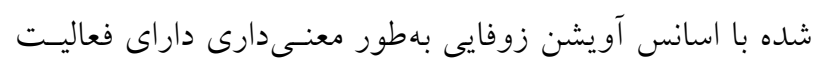

تفــاوت معنسى دارى بــين سـطوح ما او ها ميلسى مـولار اسـيد

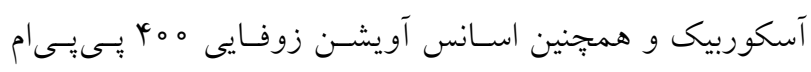

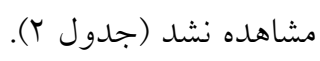
نتايج تجزيسه واريـانس دادههـا نشـان داد كـهـ اتــر تركيبـات استفاده شده و زمان بر كلـونى بـاكترى معنسى دار بـود ولسى اثتر متقابل تيمار مواد و زمان بر كلونى باكترى معنى دار نبود (جدول

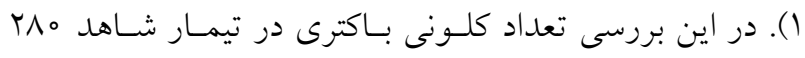

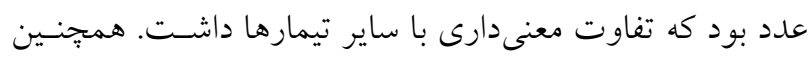

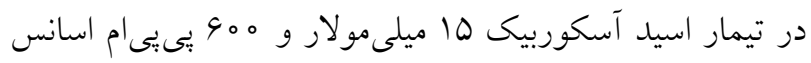

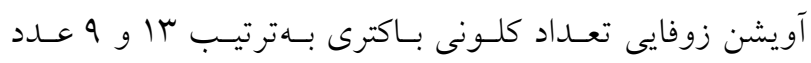

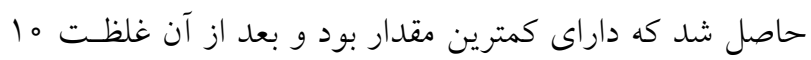

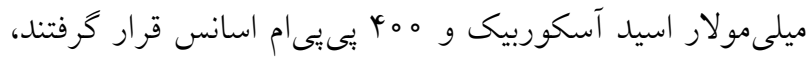
كه دو تيمار اخير تفاوت معنىدارى با يكديخر نداشتند (جـدول

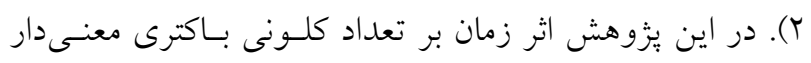

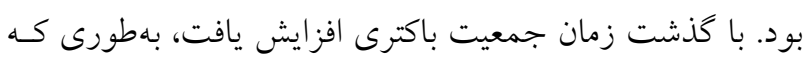

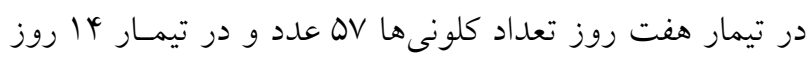

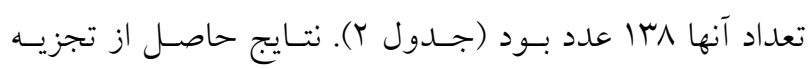

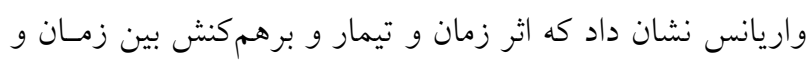

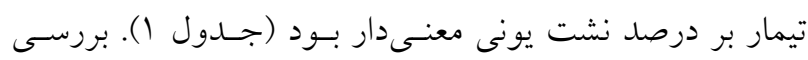

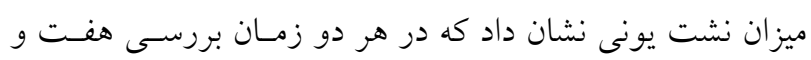

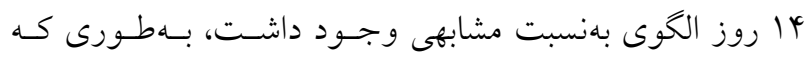

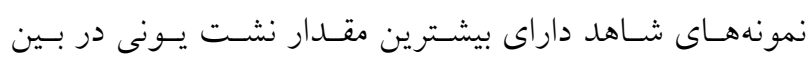

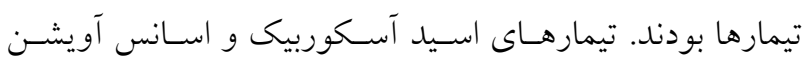
زوفايى بهطور مؤثرى مقدار نشت يونى را در مقايسه بـا شـاهد

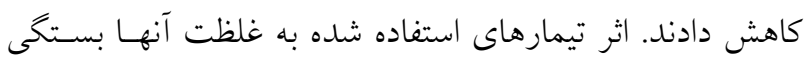

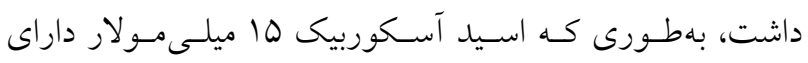
كمترين مقدار نشت يونى و بهدنبال آن سطوح هـ ه آميلسى مـولار

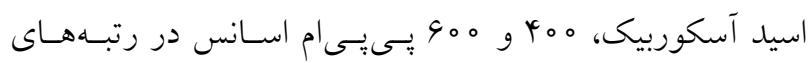

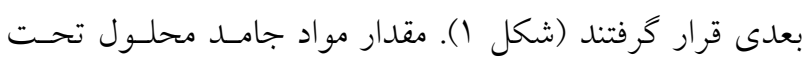

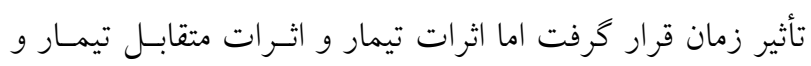
زمان بر اين شاخص معنى دار نبود (جدول () ). بيشـترين مقـدار

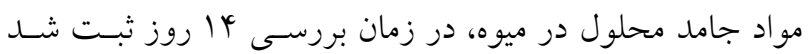




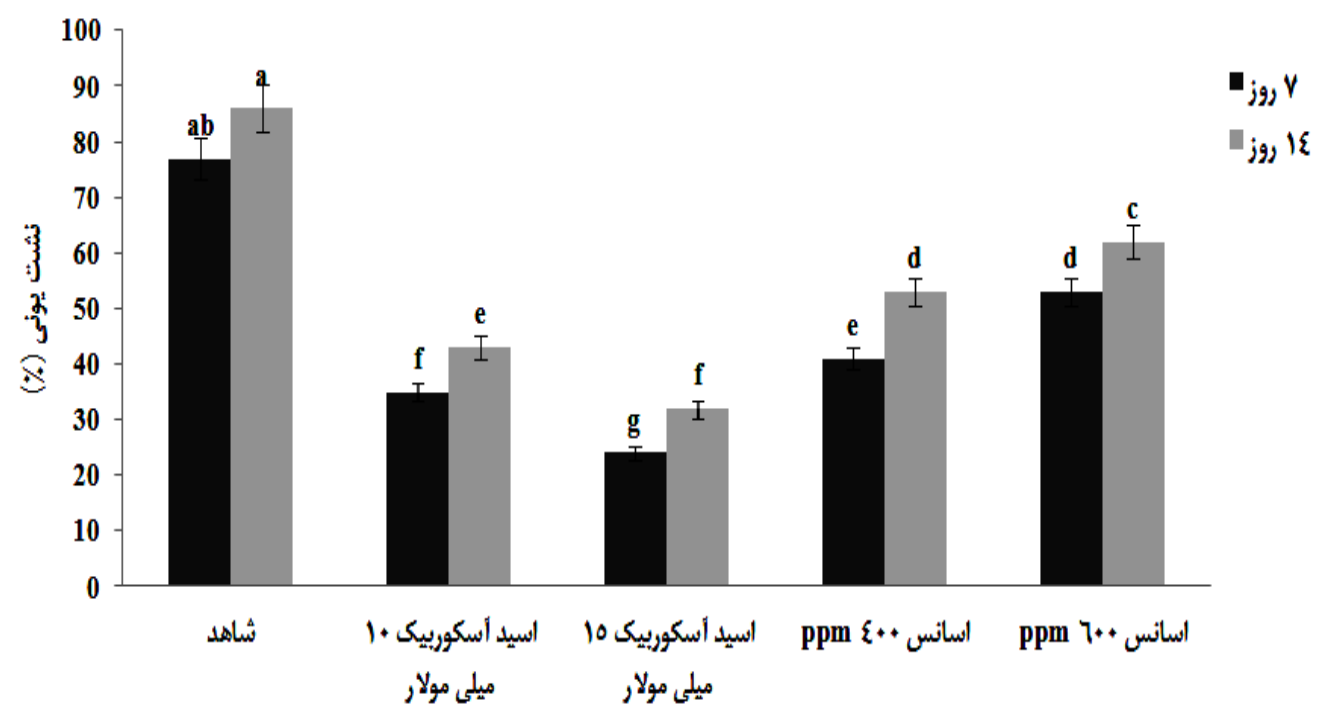

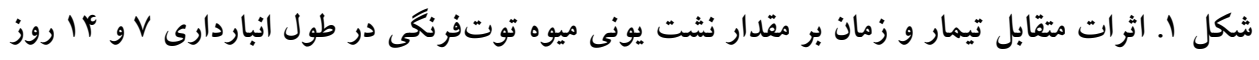

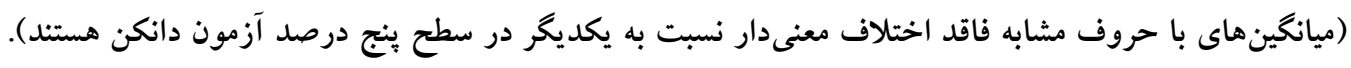

جدول r. مقايسه ميانغين اثرات زمان بر صفات كمّى و كيفى ميوه توتفرنكى بعد از انبارمانى

\begin{tabular}{|c|c|c|c|c|c|c|c|c|c|c|}
\hline 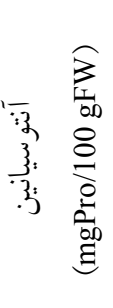 & 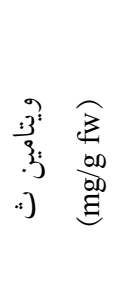 & 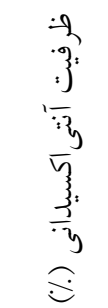 & $\begin{array}{l}\frac{2}{2} \\
y \\
3 \\
3 \\
y \\
y \\
2 \\
0\end{array}$ & $\begin{array}{l}\frac{x}{3} \\
3 \\
3 \\
\frac{3}{3} \\
3 \\
3\end{array}$ & $\stackrel{I}{2}$ & $\begin{array}{l}3 \\
3 \\
3 \\
3 \\
3 \\
3\end{array}$ & 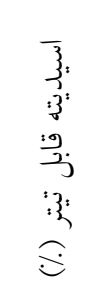 & 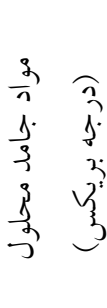 & 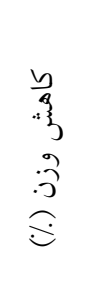 & $\begin{array}{l}3 \\
3 \\
.3 \\
3 \\
3 \\
3\end{array}$ \\
\hline $1 \Lambda / Y^{b}$ & $\circ / q^{a}$ & & $\Delta V^{b}$ & $\varphi / \mu^{a}$ & $\mu / 4 b$ & $G / N Y^{b}$ & o/Ara & $\mathrm{V} / \mathrm{N}^{\mathrm{b}}$ & $G / 1)^{b}$ & V روز \\
\hline$\left\langle/ / \gamma^{a}\right.$ & $\circ / 4 \Delta^{b}$ & $10 / 94^{b}$ & $\| \mu^{\mathrm{a}}{ }^{\mathrm{a}}$ & $\mu / \Upsilon^{b}$ & $\boldsymbol{Y} / \boldsymbol{T}^{\mathrm{a}}$ & $\wedge / \backslash \wedge^{\mathrm{a}}$ & $\circ / V^{b}$ & $1 \circ / \mathrm{V}^{\mathrm{a}}$ & $\mid Y / T y^{a}$ & ז إ روز \\
\hline
\end{tabular}

داراى مقدار فنل كمترى در مقايسه با ساير تيمارها بود و تفاوت

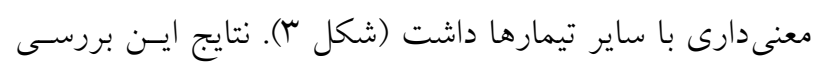
نشان داد اثرات غلظت هاى مختلف تيمارهـا و زمـان بــر مقـــار آنتى اكسيدان كل معنى دار شد، ولى اثرات متقابل تيمار و زمان بر اين شاخص معنىدار نبود. بيشترين مقدار ظرفيت آنتى اكسيدانى

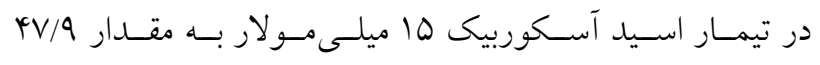
ميلى گرم بر ليتر بهدست آمد كه البته اختلاف معنى دارى با اسـيد

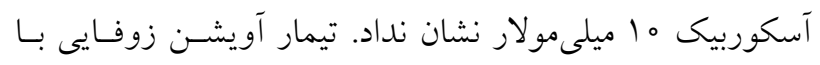

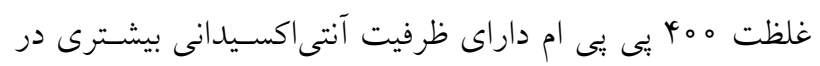
مقايسه با شاهد بود، ولى در مقايسه بـا سـطوح مختلـف اسـيد
آنزيمى كمترى در مقايسه با شاهد بودند اما در مقايسه با سطوح مختلف اسيد آسكوربيك فعاليت اين آنزيم بيشـتر بـود. در بـين غلظت هاى متفاوت اسيد آسكوربيك اختلاف معنى دارى از نظـر

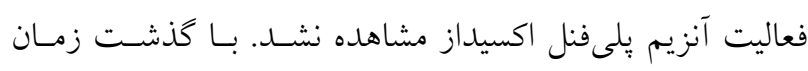
آزمايش فعاليت آنزيم بلى فنل اكسيداز افزايش بيشترى نشـان داد اثر تيمار و زمان و اثرات متقابل بين آنها بر فنل كل معنى دار

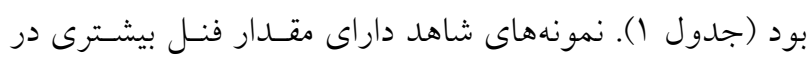
مقايسه با نمونههاى تيمار شده بـا اسـيد آسـكوربيك و اسـانس

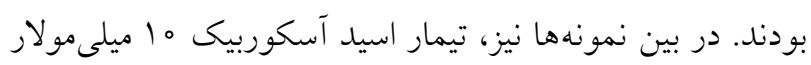




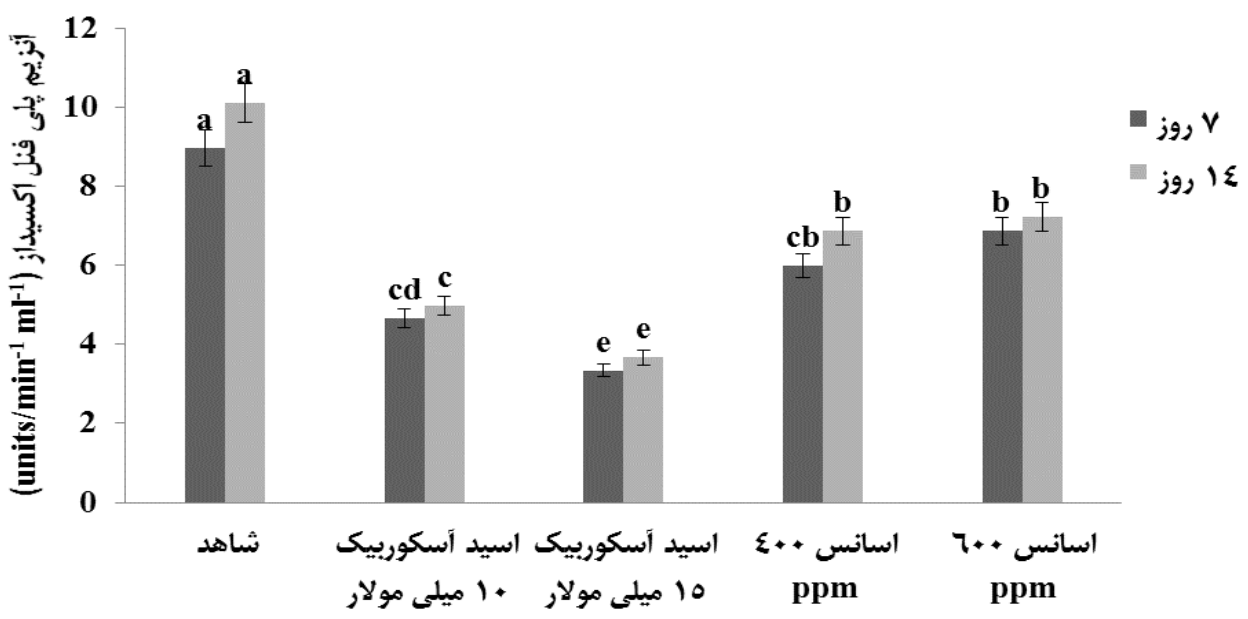

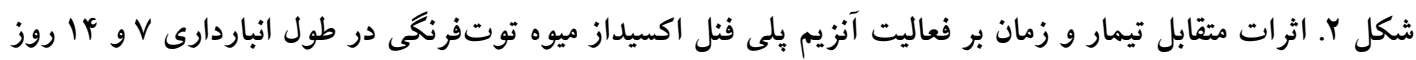

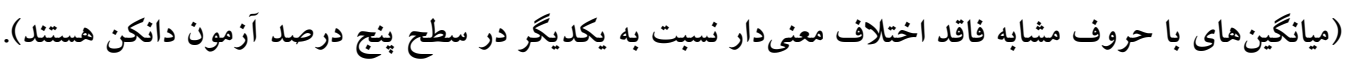

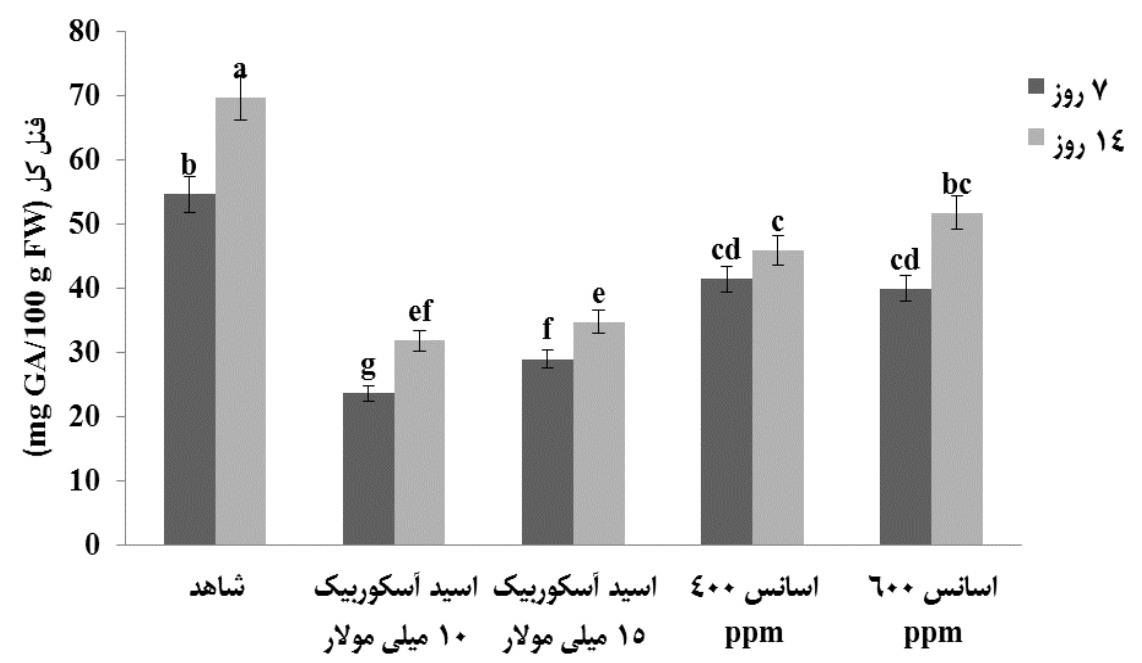

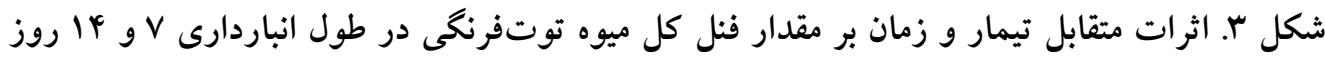
(ميانخينهاى با حروف مشابه فاقد اختلاف معنىدار نسبت به يكديخر در سطح ينج درصد آزمون دانكن هستند).

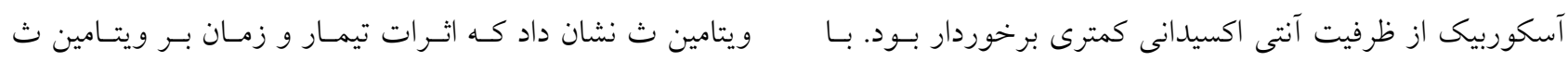

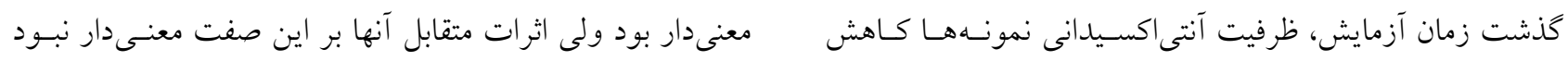

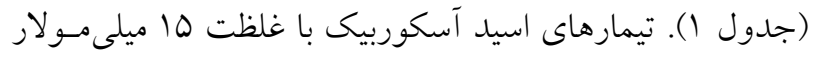
معنى دارى نشان داد (جدول ؟َ).

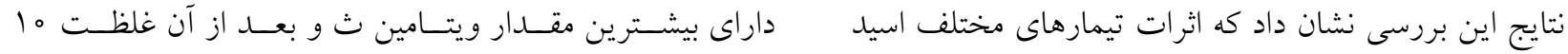

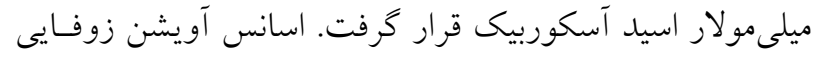

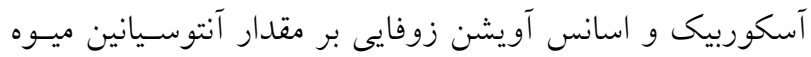

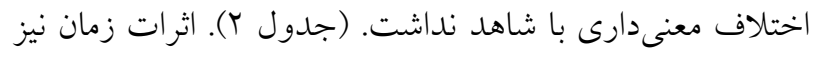
معنى دار نبود ولى اثرات زمان معنى دار شد (جدول Y). در تيمار بر اين شاخص معنى دار بود بهطورى كه بيشترين مقدار ويتامين

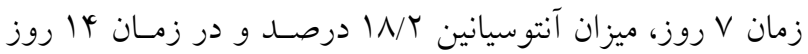

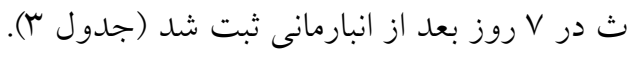

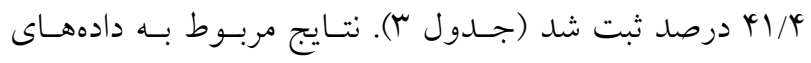


و همجنين اسيديته قابل تيتراسيون در تيمار اسيد آسكوربيك ها

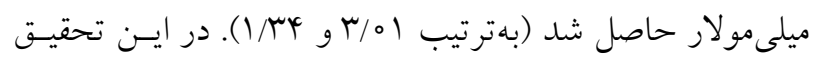
هر جنـــ اخـتلاف معنسى دارى بــين مــواد جامـــ محلـول ميـوه توتفرنكى در تيمارهاى مختلف وجود نداشت، ولى با كذشت زمان ميزان اين مـواد افـزايش يافـت. افـزايش قنـــها و كـاهش

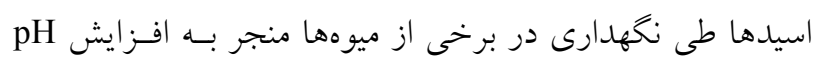
مىشود ولى اين افزايش در برخى ميوهها متفاوت اسـت، جــون علاوه بر اسيدها ساير مواد موجود در ميوه نظير قندها نيز امكان

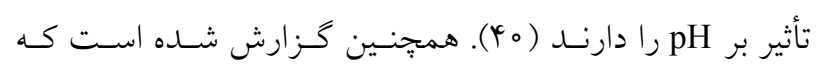
افزايش مواد جامد محلول در طـول مـدت نخهـدارى در نتيجـه كاهش آب ميوه و تجزيه قندهاى مركب به قندهاى ساده اتفـاق مىافتد (OY). قندهاى محلول بهاعنوان يك سيستم دفاعى باعثث مىشوند تا آلودگى هاى كمترى وارد بافت ميوه شود و از طرفى هرجهه ميزان قند در بافت ميوه بيشتر باشد ميزان آب موجـود در

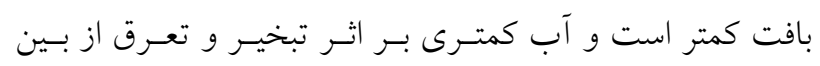

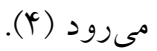
در ميوه ليجتى اسـتفاده از اسـيدهاى آلى بـهدليـل افـزايش يكيارجّى غشا مانع تخريب آنتوسيانين، كاهش اكسيداسـيون و كاهش فعاليت آنزيم بر اكسيداز مىشود. بهنظر مىرســ اسـتفاده از اين تركيبات بهطور مؤثرى مىتواند قهوهاى شدن ميـوهجـات در طول دوره انباردارى و يس از برداشت را كتــرل كنــ (هم). همجنين اثر اسيد آسكوربيك يك درصد بر كاهش قهوهاى شدن در سيب برشخـورده كـزارش شـده اسـت (YO). نقـش مثبـت اسيدهاى آلى در كاهش سرعت توليــد اتسيلن و سـرعت تـنفس كزارش شده است (آ و NY广). در ميوههاى برداشت شده، اسـيد آسكوربيك مىتواند عامل كاهش تنفس و توليد اتيلن بوده و بـا افزايش يتانسيل آنتى اكسيدانى محصول از اكسيداسيون جربىهـا جلوكيرى كند (11). بنابراين بـهنظـر مسىرســ يكسى از دلايـل ماندكارى بافت ميوه توسـط تيمارهـاى اسـيد آلى ممانعـت از افزايش توليد اتيلن و كاهش آلودگى با ميكروارگانيسمها در اثـر

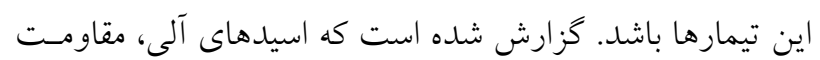
بافت ميوه را در برابر افزايش فعاليت آنزيم بلى فنـول اكسـيداز
كيفيت ظاهرى محصول بهعنـوان مهــم تـرين شـاخص ارزيـابى

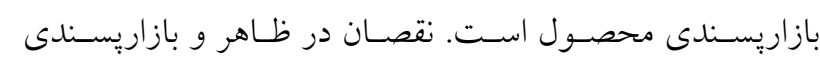
محصولات تازه ناشى از نابسـامانىهـاى فيزيولـوزيكى و بــروز

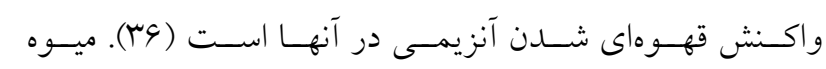

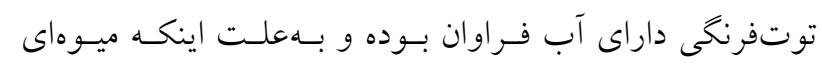
نافرازگرا است بايد در زمان رسيدكى برداشـت شـود، بـهمهـين علت ماندكارى يس از برداشت كوتاهى دارد. طى نخهـدارى در

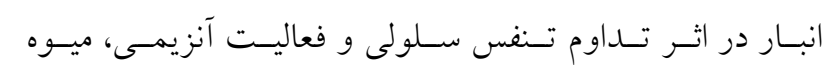
توتفرنخى در ابتدا نرم شده و سبس حالت لهيده بيدا مسى كنـد.

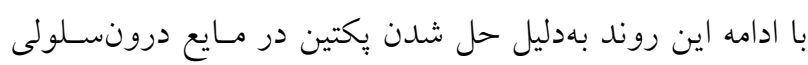
كيكزدگى مشاهده مىشود (9) (1). بر اساس نتايج اين بيزوهش و تأثير تركيبات اعمال شده روى ميوه توتفرنخى مسى مــوان بيـان داشت كه از ميان تيمارهاى اعمال شده، بهترين نتايج در كيفيـت و ظاهر ميوه در تيمارهاى اسيد آسكوربيك مشاهده شده اسـت.

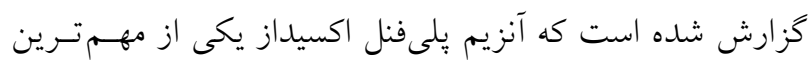

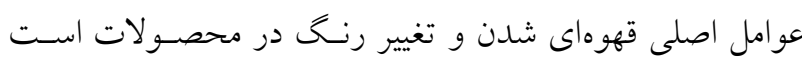
(YD) ). واكنش قهوهاى شدن باعث ايجاد يك تغيير نـامطلوب در بافت مىشود كه بر طعم، ظاهر و كيفيت ميوه اثر منفى دارد. در مطالعات قبلى كزارش شده كه اسيد آسكوربيك بهطور مناسـبى

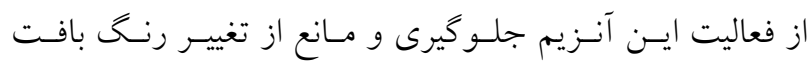
مىشود (4)). در آزمايشى مشابه، گزارش شده است كه واكنش

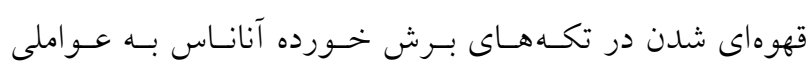

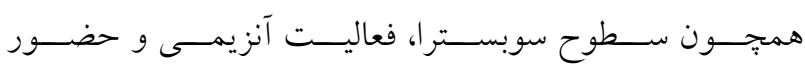
بازدارندههاى قارجى بستخى دارد، و ذكر شده كه كـاربرد اسـيد آسكوربيك، واكنش قهوهاى شـدن در تكسههـاى بــرش خــورده آناناس را بهطور معنى دارى كاهش داده است (Yo). كاربرد اسيد آسكوربيك تأثير معنى دارى بر ميـزان pH داشـت كـهـ مسىتـوان

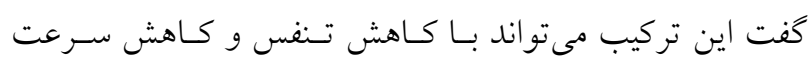

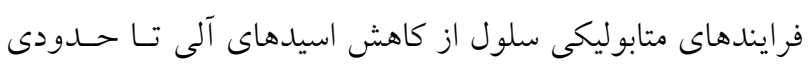
جلو گيرى كند كه در بلندمدت باعـث تجمـع اسـيدهاى آلى و افت pH ميوه مىشود. در مطالعه حاضر كمترين ميزان pH ميـوه 
بهخود اختصاص ميدهد، تبديل مىشود.

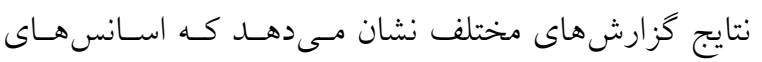
كياهان دارويى بهدليل خاصيت ضدميكروبى مى تو انند در كنتـرل

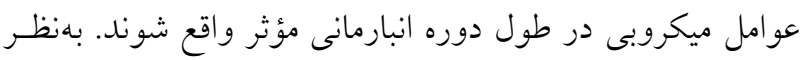

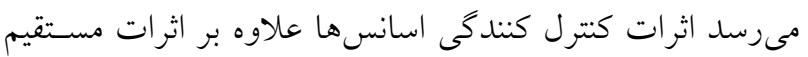

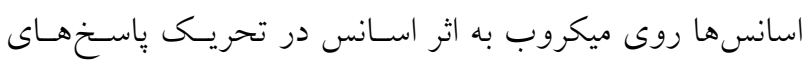

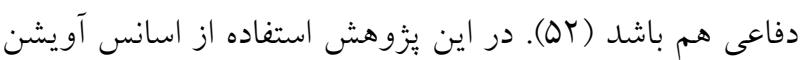
زوفايى، نسبت به كياهان شاهد، باعث بهبود ويزگى هاى كيفى و

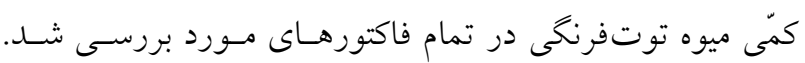

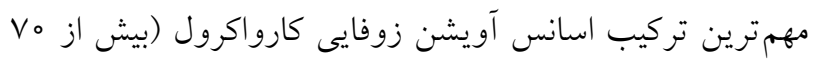

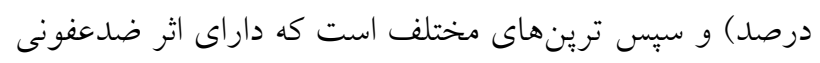

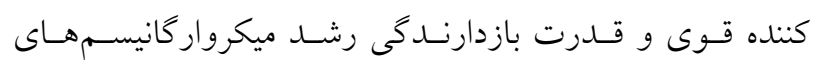

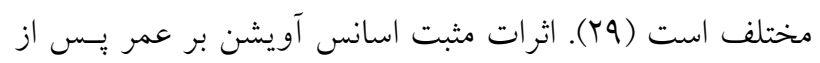

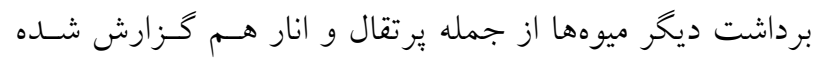

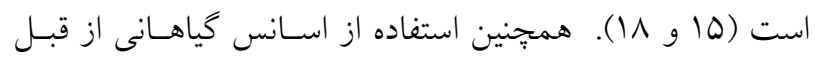

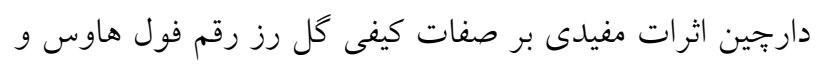

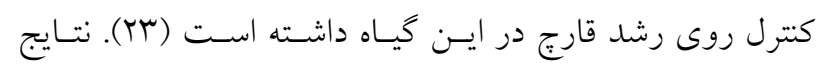

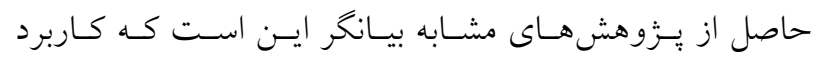
اسانسهاى كيـاهى سـبب جلـو گيرى از فعاليـت سـريع آنـزيم

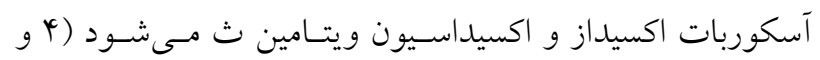

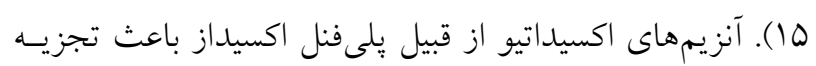

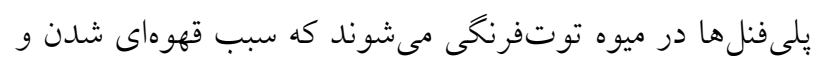

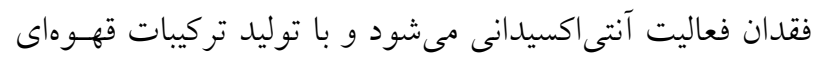

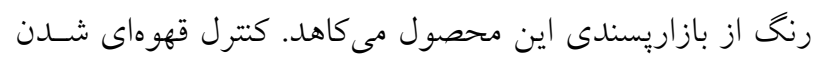

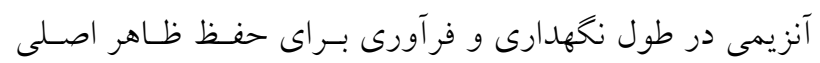

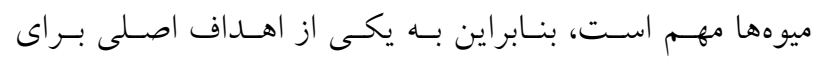

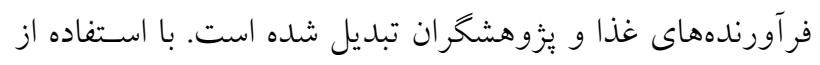

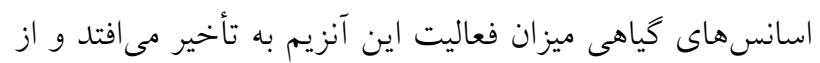

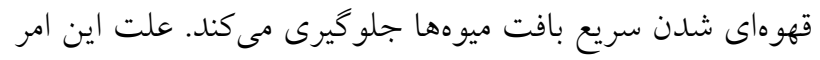

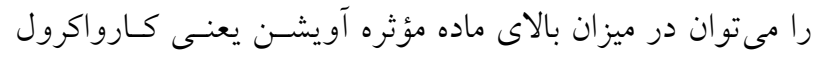

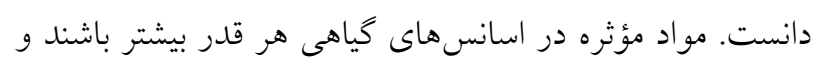

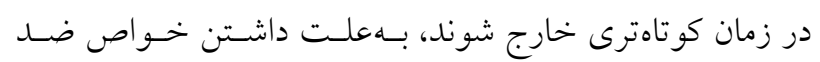

افزايش داده و با ضدعفونى بافت ميوه از رشد و فعاليت عوامـل

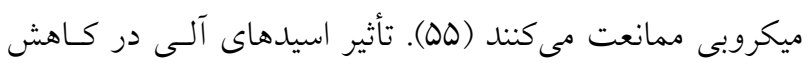

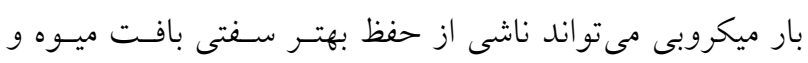

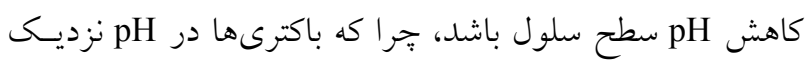

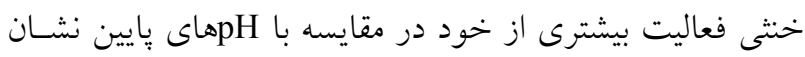

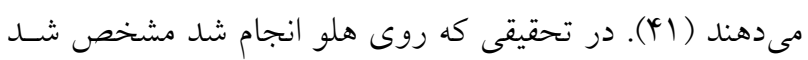

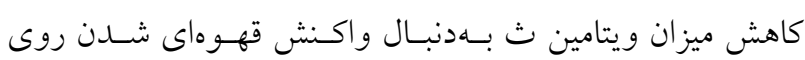

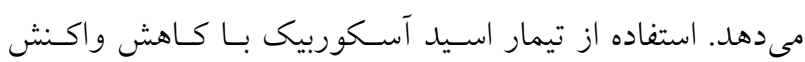

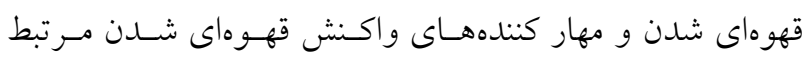

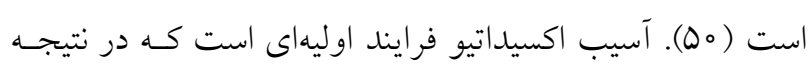

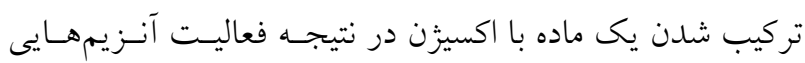

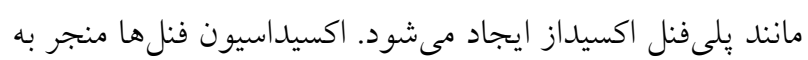

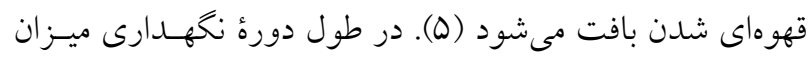

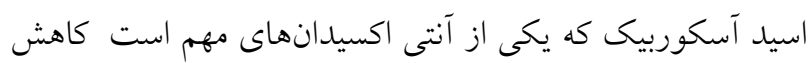

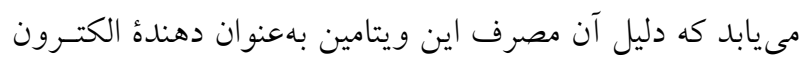

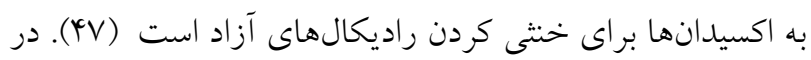

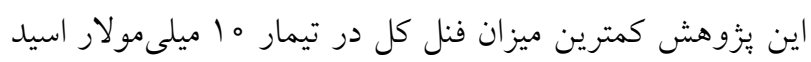

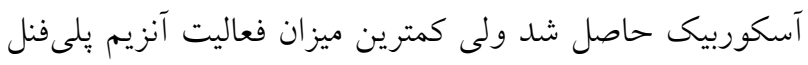

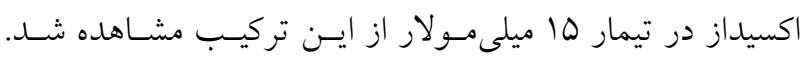
ميزان نشت يونى روندى مشابه با فعاليت آنزيم بلى فيلن اكسيداز

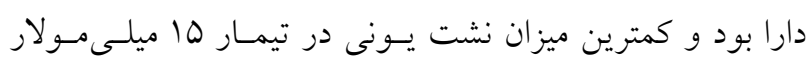
اسيد آسكوربيك مشاهله شد.

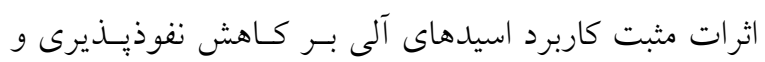

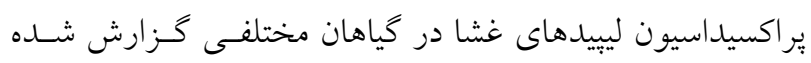

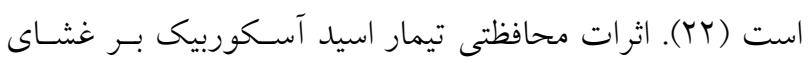

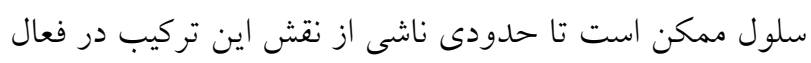

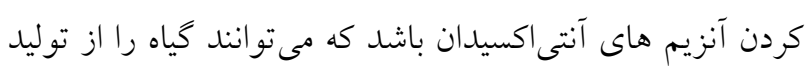
كونههاى فعال اكسيزن حفظ كنند. همانطور كه انتظار مىرفت،

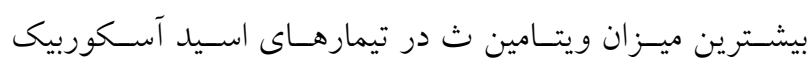
مشاهده شد. كاهش مقدار ويتامين ث بهعلت اكسيداسيون اسيد آسكوربيك است كه توسط آنزيم آسـكوربات اكسيداز انجـام

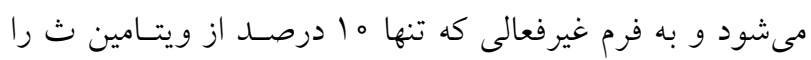




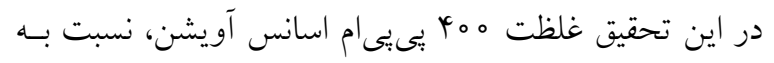

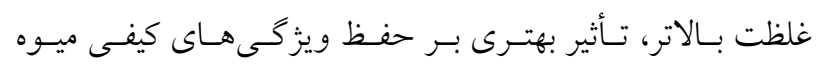
توتفرنكى دارا بود. بهعبـارتى ديخـر غلظـت كمتـر اسـانس اثـر مفيدترى نسبت به غلظت بيشـتر آن داشـت كـه مشـابه بـا نتـايج حاصل از كاربرد اسانس گياهى بر سيب رقم گلدن دليشـز، زربــرا

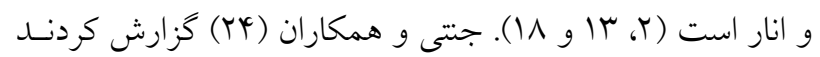

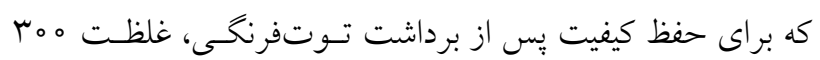

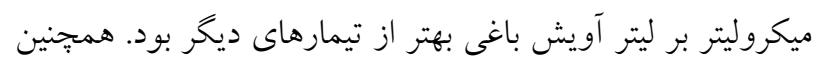
كزارش شده كه غلظت بـالاى اسـانس اسـطوخودوس و ريحـان تأثيرات منفى در كيفيت يس از برداشت ميوه توتفرنخـى داشـته

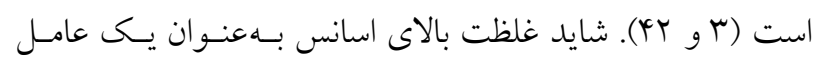
تنشزا سبب افزايش فعاليتهاى حياتى سلول شده و مواد غذايى ذخيره شده در ميوه را به مصرف برساند. اسانسها در سلولهـاى يوكاريوتى مىتوانند قطبزدايى غشاهاى ميتو كندرى را بـهوسـيله

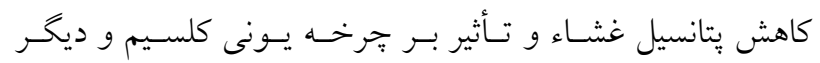
كانالهاى يونى و شيب pH تحريك كنند (Y (Y). اسانسها سياليت

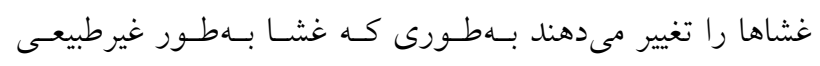
نقوذيذير شده و منجر به نشت راديكالها، سيتوكروم c، يونهـاى كلسـيم و يـروتئينهـا شـده و درنهايست باعـث تسنش اكسـيداتيو

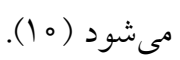

\section{نتيجه گيرى}

نتايج كلى نشان داد ميوه توتفرنخـى بـهــرعت در طى دوره

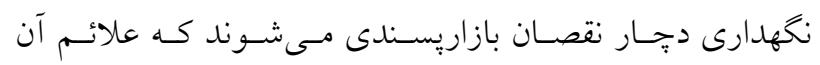
دربر گيرنسده كـاهش وزن و قهـوهاى شـدن سـطح ميسوه اسـت.

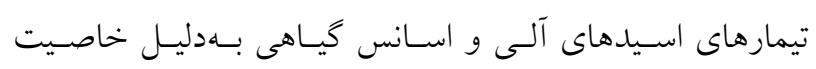
ضدقهوهاى شدن و آنتى اكسيدانى منجر به افزايش عمر قفسـهاى ائ در ميوه توتفرنكى شدند. اين تيمارهـا باعـث كـاهش فعاليـت

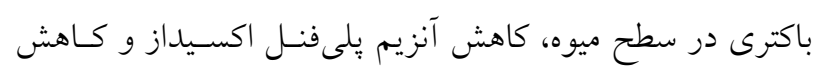

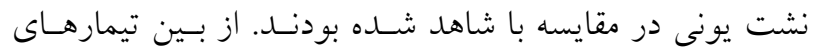
استفاده شده، تيمار اسيد آسكوربيك در غلظت بالاتر در كنتـرل

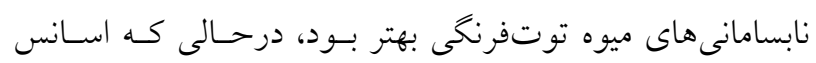

ميكروبى نتايج مطلوبترى در نخهـدارى و حفظظ عمـر انبـارى محصولات خواهند داشت. از بين فاكتورهاى اندازهخيـرى شـده در اين تحقيق، اسانس آويش زوفايى فقط در كترل رشد كلونى باكتريايى نسبت به اسيد آسـكوربيكى عملكــــ بهتـرى از خـود

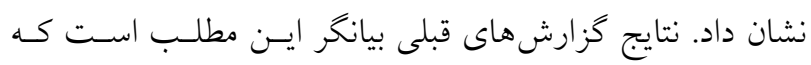

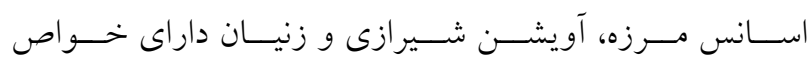
ضدميكروبى بوده و بهطور مؤثرى قادر به مهار بيمارىهاى يسس از برداشت ميوه توتفرنخى هستند (N). بهنظر مىرسد تـأثير ضدميكروار كانيسـمى اسـانس آويشـن

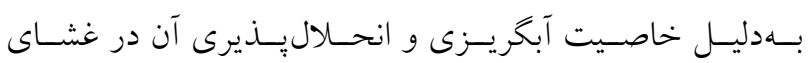
سيتويلاسمى و تشكيل باندهاى هيدروزنى توسط تركيبات فنلى آن با يروتيئنهاى غشاى سيتويهاسمى قـارج بعــ از تجزيـهـ در

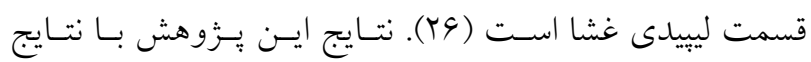
عبداللهى و همكاران ( (1) در مورد تأثير اسانس هاى رازيانه، زيره سياه و زنيان روى كوجه فرنخى و همجنين با نتـايج حاصـل از

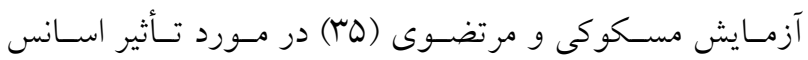
آويشن و اسانس زنيان روى كابعى و غفورى و همكـاران (1/) در مورد اثر اسانس آويشن بر انار مطابقت دارد. همجنِين تأثير مثبت اسانس آويشن در كاهش نشت يـونى و افزايش بازاريسندى در زمان انبارمـانى قابـل توجـهـ بـود. نتـايج

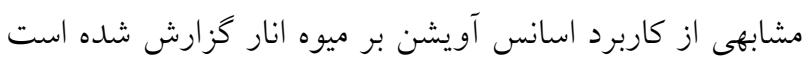

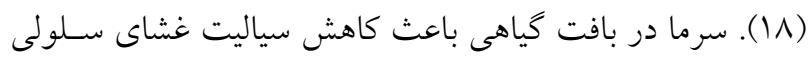
و بروز سرمازدگى در غشاى سلولى آسيب ديــه مسى شـود كـه.

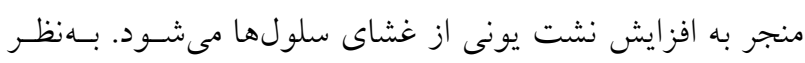

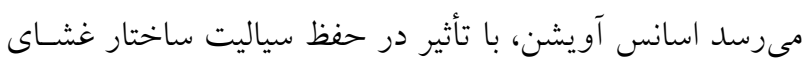

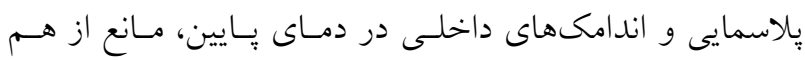
ياشيده آنها شده و درنتيجه باعـث كنتـرل نشـت يـونهـا شــود. تركيبات فنلى، كه از مهمترين تركيبات اسانس آويشـن زوفـايى

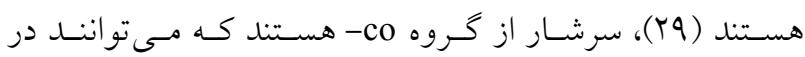
متلاشى كردن راديكالهاى آزاد بهوجود آمده در اثر تنش سـرما نقش مهمى بازى كرده و منجر به كـاهش سـرمازدگى در بافـت ميوهها شود. 


$$
\begin{aligned}
& \text { آويشن در كنترل كلونى هاى باكترى بهتر از ديخر تيمارهـا عمـل تشكر و قدردانى }
\end{aligned}
$$

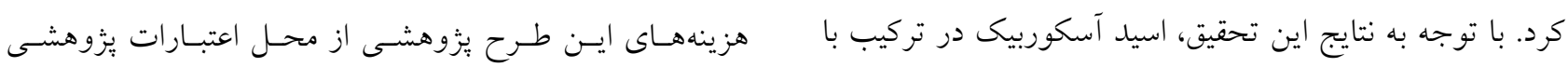

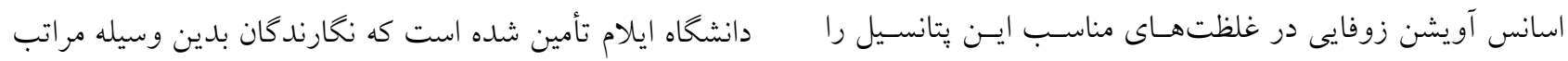

$$
\begin{aligned}
& \text { دارند براى كنترل نابسامانى هاى يسس از برداشـت تـوت فرنخـى قدردانى خود را ابراز مى دارند. } \\
& \text { معرفى شوند. }
\end{aligned}
$$

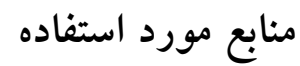

1. Abdolahi, A., A. Hassani, Y. Ghuosta, T. Javadi and M. H. Meshkatalsadat. 2010. Essential oils as control agents of Post-harvest Alternaria and Penicillium rots on tomato fruits. Journal of Food Safety 30: 341-352.

2. Aboutalebi, A. and A. Sami. 2012. Evaluation the antifungal effect of fennel essence on post harvest life of golden delicious apple and comparison its effect with carbendazim and thiabendazole fungicide. International Research Journal of Applied and Basic Sciences 3: 2104-2107.

3. Asghari Marjanlo, A., Y. Mostoufi, S. H. Shoeybi and M. Maghoumi. 2008. Effect of Basil essential oil on gray mold control and postharvest quality of strawberry. Journal of Medicinal Plants 28: 131-139.

4. Atress, S. H., M. M. El-Mogy, H. E. Aboul-Anean and B. W. Alsanius. 2010. Improving strawberry fruit storability by edible coating as a carrier of thymol or calcium chloride. Journal of Horticultural Science \& Ornamental Plants 2: 88-97.

5. Ayala-Zavala, J. F., S. Y. Wang, C. Y. Wang and G. A. González-Aguilar. 2004. Effect of storage temperatures on antioxidant capacity and aroma compounds in strawberry fruit. LWT-Food Science and Technology 37: 687-695.

6. Babazadeh, D. B. 2013. Comparison of vitamin C in Mandarin (Citrus Blanco.) cultivars. Eco-Phytochemical Journal of Medical Plants 1: 82-93.

7. Barth, C., M. Detullio and P. L. Conklin. 2006. The role of ascorbic acid in the control of flowering time and the onset of senescence. Journal of Experimental Botany 57: 1657-1665.

8. Behdad, M., N. A. Etemadi, E. Behdad and H. Zeinali. 2013. Antifungal effects of three plant essential oils against Rhizopus stolonifer, the cause of soft rot on strawberry fruit. Iranian Journal of Medicinal and Aromatic Plants 29: 399-411. (In Farsi).

9. Boquete, E. J., G. D. Trinchero, A. A. Fraschina, F. Vilella and G. O. Sozzi. 2004. Ripening of 'Hayward'kiwifruit treated with 1-methylcyclopropene after cold storage. Postharvest Biology and Technology 32: 57-65.

10. Bruni, R., A. Medici, E. Andreotti, C. Fantin, M. Muzzoli and M. Dehesa. 2003. Chemical composition and biological activities of Isphingo essential oil, a traditional Ecuadorian spice from Ocotea quixos (lam) kosterm.(lauraceae) flower calkes. Food Chemistry 85: 415-421.

11. Cioroi, M. 2007. Study on L-ascorbic acid contents from exotic fruits. Cercetari Agronomicin Moldova 1: 23-27.

12. Corrales-Garcıa, J., C. B. Peña-Valdivia, Y. Razo-Martínez and M. Sánchez-Hernández. 2004. Acidity changes and pH-buffering capacity of nopalitos (Opuntia spp.). Postharvest Biology and Technology 32: 169-174.

13. Dareini, H., V. Abdos and E. Danaee. 2014. Effect of some essential oils on postharvest quality and vase life of gerbera cut flowers (gerbera jamesonii cv. Sorbet). European Journal of Experimental Biology 4: 276-280.

14. Eckert, J. W. and J. M. Ogawa. 1988. The chemical control of postharvest diseases: deciduous fruits, berries, vegetables and root/tuber crops. Annual Review of Phytopathology 26: 433-469.

15. Fatemi, S., M. Jafarpour and S. H. Eghbalsaeid. 2011. Study of the effect of Thymus vulgaris and hot water treatment on storage life of orange (Citrus sinensis CV. Valencia). Journal of Medicinal Plants Research 6: 968-971.

16. Ferrari, C. C., C. I. Sarantopoulos, S. M. Carmello-Guerreiro and M. D. Hubinger. 2013. Effect of osmotic dehydration and pectin edible coatings on quality and shelf life of fresh-cut melon. Food and Bioprocess Technology 6: 80-91.

17. Fisk, C. L., A. M. Silver, B. C. Strik and Y. Zhao. 2008. Postharvest quality of hardy kiwifruit (Actinidia arguta 'Ananasnaya') associated with packaging and storage conditions. Postharvest Biology and Technology 47: 338-345.

18. Ghafouri, B., A. Carlsson, S. Holmberg, A. Thelin and C. Tagesson. 2016. Biomarkers of systemic inflammation in farmers with musculoskeletal disorders; a plasma proteomic study. BMC Musculoskeletal Disorders 17: 1-11.

19. Ghasemnezhad, M., M. A. Nezhad and S. Gerailoo. 2011. Changes in postharvest quality of loquat (Eriobotrya japonica) fruits influenced by chitosan. Horticulture, Environment, and Biotechnology 52: 40-45.

20. González-Aguilar, G. A., S. Ruiz-Cruz, H. Soto-Valdez, F. Vázquez-Ortiz, R. Pacheco-Aguilar and C. Y. Wang. 2005. Biochemical changes of fresh-cut pineapple slices treated with antibrowning agents. International Journal of 
Food Science \& Technology 40: 377-383.

21. Han, T., Y. Wang, L. Li and X. Ge. 2002. Effect of exogenous salicylic acid on post harvest physiology of peaches. In: XXVI International Horticultural Congress: Issues and Advances in Postharvest Horticulture.

22. Horvath, E., G. Szalai and T. Janda. 2007. Induction of abiotic stress tolerance by salicylic acid signaling. Plant Growth Regulation 26: 290-300.

23. Hosein Zade, E. 2010. Effect of salicylic acid and calcium salts and essential oils of rose and disease control Botrytis cinerea on the quality of cut flowers in the full house. MSc Thesis, Islamic Azad University of Science and Research Branch of Tehran. Iran. (In Farsi).

24. Jannati, M., V. Abdossi and M. Mashhadi Akbar Boujar. 2014. Effect of calcium chloride and thyme essential oils application on some postharvest characteristics of strawberry fruit cv. Selva. Agroecology Journal 10: 25-32. (In Farsi).

25. Jeong, H. L., W. J. Jin, D. M. Kwang and J. P. Kee. 2008. Effects of anti-browning agents on polyphenoloxidase activity and total phenolics as related to browning of fresh-cut 'Fuji'apple. Asean Food Journal 15: 79-87.

26. Juven, B. J., J. Kanner, F. Sched and H. Weisslowicz. 1994. Factors that interact with the antimicrobial of thyme essential oil and its active constituent's. Journal of Applied Bacteriology 76: 626-631.

27. Kähkönen, M. P., A. I. Hopia and M. Heinonen. 2001. Berry phenolics and their antioxidant activity. Journal of Agricultural and Food Chemistry 49: 4076-4082.

28. Khosheghbal, F., M. Ghorbanli and R. Hajihosseini. 2010. Effect of zinc sulfate stress and its interaction with ascorbic acid on some physiological parameters in Brassica napus. Rostaniha 11: 93-102. (In Farsi).

29. Kilic, T. Z. 2006. Analysis of essential oil composition of Thymbra spicata var. spicata: antifungal, antibacterial and antimycobacterial activities. Zeitschrift fur Naturforschung 61: 324-328.

30. Lutts, S., J. M. Kinet and J. Bouharmont. 1996. NaCl-induced senescence in leaves of rice (Oryza sativa L.) cultivars differing in salinity resistance. Annals of Botany 78: 389-398.

31. Martínez-Romero, D., N. Alburquerque, J. M. Valverde, F. Guillén, S. Castillo, D. Valero and M. Serrano. 2006. Postharvest sweet cherry quality and safety maintenance by Aloe vera treatment: a new edible coating. Postharvest Biology and Technology 39: 93-100.

32. Mohammadi, S., H. Aroui, A. Tehranifar and V. Jahanbakhsh. 2012. Application of essential oil of medicinal plants on the postharvest decay resulted from Botrytis cinerea on strawberry (cv. Selva). Physiology and Technology of Postharvest in Horticultural Crops 1: 55-73. (In Farsi).

33. Mostofi, Y. and A. Asgharimarjanlo. 2010. The effect of UV-C radiation on gray mold decay control and postharvest quality of strawberry (cv. Selva). Iranian Horticulture Journal 41: 39-46. (In Farsi).

34. Munsch, P., K. Johnstone and T. Alatossava. 2002. Evidence for genotypic differences between the two siderovars of Pseudomonas tolaasii, cause of brown blotch disease of the cultivated mushroom Agaricus bisporus. Microbiological Research 157: 93-102.

35. Muscovi, A. and A. Mortazavi. 2004. Antifungal activity of Essential oils of Thymus vulgaris and Trachyspermum ammi against Aspergilus. Journal of Science and Technology of Agriculture and Natural Resources 8: 207-214. (In Farsi).

36. Oms-Oliu, G., M. A. Rojas-Graü, L. A. Gonzalez, P. Varela, R. Soliva-Fortuny, M. I. H. Hernando, I. P. Munuera, S. Fiszman and O. Martín-Belloso. 2010. Recent approaches using chemical treatments to preserve quality of freshcut fruit: A review. Postharvest Biology and Technology 57: 139-148.

37. Pizzocaro, F., D. Torreggiani and G. Gilardi. 1993. Inhibition of apple polyphenoloxidase (PPO) by ascorbic acid, citric acid and sodium chloride. Journal of Food Processing and Preservation 17: 21-30.

38. Plaza, P., R. Torres, J. Usall, N. Lamarca and I. Vinas. 2004. Evaluation of the potential of commercial post-harvest application of essential oils to control citrus decay. The Journal of Horticultural Science and Biotechnology 79: 935-940.

39. Ranjbar, H., M. Farzaneh, R. Sharifii, J. Hadian and M. H. Mirjalili. 2008. Classification of selected mul-ticut Persian clover germplasm of National Plant Genebank based on agronomic traits. Pajouhesh \& Sazandegi 81: 5460. (In Farsi).

40. Raskin, I. 1992. Salicylic, a new plant hormone. Plant Physiology 99: 799-803.

41. Ruíz-Jiménez, J. M., P. J. Zapata, M. Serrano, D. Valero, D. Martínez-Romero, S. Castillo and F. Guillén. 2014. Effect of oxalic acid on quality attributes of artichokes stored at ambient temperature. Postharvest Biology and Technology 95: 60-63.

42. Sayari, M. and R. Gharibi. 2016. Effects of Lavendula essential oils and Methyl Salicilate on mouldy grey and fruit quality of strawberry. Journal of Horticultural Science 29: 662-670. (In Farsi).

43. Serrano, M., F. Guillén, D. Martínez-Romero, S. Castillo and D. Valero. 2005. Chemical constituents and antioxidant activity of sweet cherry at different ripening stages. Journal of Agricultural and Food Chemistry 53: 2741-2745.

44. Singleton, V. L., R. Orthofer and R. M. Lamuela-Raventós. 1999. Analysis of Total Phenols and others Oxidation Substrates and Antioxidants by Means of Folin-Ciocalteu Reagent. London. 
45. Smirnoff, N. 2000. Ascorbic acid: metabolism and functions of a multi-facetted molecule. Current Opinion in Plant Biology 3: 229-235.

46. Smirnoff, N. and G. L. Wheeler. 2000. Ascorbic acid in plants: biosynthesis and function. Critical Reviews in Biochemistry and Molecular Biology 35: 291-314.

47. Spinardi, A. M. 2004. Effect of harvest date and storage on antioxidant systems in pears. Acta Horticulturae 682: 135-140.

48. Srivastava, M. K. and U. N. Dwivedi. 2000. Delayed ripening of banana fruit by salicylic acid. Plant Science 158 : 87-96.

49. Suttirak, W. and S. Manurakchinakorn. 2011. Potential application of ascorbic acid, citric acid and oxalic acid for browning inhibition in fresh-cut fruits and vegetables. Walailak Journal of Science and Technology 7: 5-14.

50. Veltman, R. and A. Van Schaik. 1997. Membrane demage in fruits perhaps the explanation of hollow core and flesh browning. Fruitteelt 87: 12-13.

51. Vitoratos, A., D. Bilalis, A. Karkanis and A. Efthimiadou. 2013. Antifungal activity of plant essential oils against Botrytis cinerea, Penicillium italicum and Penicillium digitatum. Notulae Botanicae Horti Agrobotanici ClujNapoca 41: 86 .

52. Wang, C. Y. and J. G. Buta. 2003. Maintaining quality of fresh-cut kiwifruit with volatile compounds. Postharvest Biology and Technology 28: 181-186.

53. Whangchai, K., K. Saengnil and J. Uthaibutra. 2006. Effect of ozone in combination with some organic acids on the control of postharvest decay and pericarp browning of longan fruit. Crop Protection 25: 821-825.

54. Wills, R., L.Terry and D. Graham. 1990. Postharvest: An Introduction to the Physiology and Handling of Fruits and Vegetables. Springer.

55. Zheng, X. L. and S. P. Tian. 2006. Effect of oxalic acid on control of postharvest browning of litchi fruit. Food Chemistry 96: 519-523. 


\title{
Effect of Ascorbic Acid and Essential Oil of Thymbra spicata on Shelf Life and Quality Maintenance of Strawberry
}

\author{
J. Erfani-Moghadam ${ }^{1^{*}}$ and O. Mohammadi²
}

(Received: January 21-2018; Accepted: January 25-2021)

\begin{abstract}
Aiming at finding a suitable treatment for maintaining the fruit quality and increase the shelf life of strawberry, effects of ascorbic acid and essential oil of Thymbra spicata were evaluated. Fruits were dipped in 10 and $15 \mathrm{mM}$ of ascorbic acid and essential oil of $T$. spicata $(400$ and $600 \mathrm{ppm})$ for two minutes, and after drying at room temperature, were packed by cellophane in the polyethylene container and transferred to $4{ }^{\circ} \mathrm{C}$. Some of the qualitative, quantitative and biochemical parameters were measured at 7 and 14 days after storage. Results of analysis of variance showed that there were significant differences among the treatments in most of the evaluated parameters. Strawberry fruits treated with ascorbic acid and essential oil showed lower weight loss and lower fruit browning, while they had higher marketability than control plants. Ascorbic acid and essential oil treatments also led to decreases in polyphenol oxidase activity, total phenol content and electro leakage, while the vitamin $\mathrm{C}$ content and antioxidant capacity were significantly higher than control plants. Generally, ascorbic acid $(15 \mathrm{mM})$ and essential oil $(400 \mathrm{ppm})$ compounds reduced fruit's degradation during cold storage and these treatments have the potential to be used as practical postharvest treatments to retain the quality of strawberry fruits.
\end{abstract}

Keywords: Strawberry, Antioxidant capacity, Vitamin C, Polyphenol oxidase

1, 2. Associate Professor and Former M.Sc. Student, Respectively, Department of Horticulture, Faculty of Agriculture, Ilam University, Ilam, Iran.

*: Corresponding Author, Email: j.erfani@ilam.ac.ir 